\title{
Winters are changing: snow effects on Arctic and alpine tundra ecosystems ${ }^{1}$
}

Christian Rixen, Toke Thomas Høye, Petr Macek, Rien Aerts, Juha M. Alatalo, Jill T. Anderson, Pieter A. Arnold, Isabel C Barrio, Jarle W. Bjerke, Mats P. Björkman, Daan Blok, Gesche Blume-Werry, Julia Boike, Stef Bokhorst, Michele Carbognani, Casper T. Christiansen, Peter Convey, Elisabeth J. Cooper, J. Hans C. Cornelissen, Stephen J. Coulson, Ellen Dorrepaal, Bo Elberling, Sarah C. Elmendorf, Cassandra Elphinstone, T'ai G.W. Forte, Esther R. Frei, Sonya R. Geange, Friederike Gehrmann, Casey Gibson, Paul Grogan, Aud Helen Halbritter, John Harte, Gregory H.R. Henry, David W. Inouye, Rebecca E. Irwin, Gus Jespersen, Ingibjörg Svala Jónsdóttir, Ji Young Jung, David H. Klinges, Gaku Kudo, Juho Lämsä, Hanna Lee, Jonas J. Lembrechts, Signe Lett, Joshua Scott Lynn, Hjalte M.R. Mann, Mikhail Mastepanov, Jennifer Morse, Isla H. Myers-Smith, Johan Olofsson, Riku Paavola, Alessandro Petraglia, Gareth K. Phoenix, Philipp Semenchuk, Matthias B. Siewert, Rachel Slatyer, Marko J. Spasojevic, Katharine Suding, Patrick Sullivan, Kimberly L. Thompson, Maria Väisänen, Vigdis Vandvik, Susanna Venn, Josefine Walz, Robert Way, Jeffrey M. Welker, Sonja Wipf, and Shengwei Zong

\footnotetext{
Received 14 January 2021. Accepted 21 January 2022.

C. Rixen.* WSL Institute for Snow and Avalanche Research SLF, Flüelastr. 11, Davos Dorf, 7260, Switzerland; Climate Change, Extremes and Natural Hazards in Alpine Regions Research Centre CERC, Davos Dorf, Switzerland.

T.T. Høye and H.M.R. Mann. Department of Ecoscience and Arctic Research Centre, Aarhus University, C.F. Møllers Allé 4-8, 8000, Aarhus C, Denmark.

P. Macek. Institute of Hydrobiology, Biology Centre of Czech Academy of Sciences, Na Sadkach 7, 370 05, Ceske Budejovice, Czech Republic.

R. Aerts, S. Bokhorst, and J.H.C. Cornelissen. Department of Ecological Science, VU University Amsterdam, De Boelelaan 1085, $1081 \mathrm{HV}$, Amsterdam, The Netherlands.

J.M. Alatalo. Environmental Science Center, Qatar University, Doha, Qatar.

J.T. Anderson. Genetics Department, University of Georgia, Athens, GA 30602-7223, USA.

P.A. Arnold and R. Slatyer. Division of Ecology and Evolution, Research School of Biology, The Australian National University, Canberra, ACT, Australia.

I.C. Barrio. Faculty of Environmental and Forest Sciences, Agricultural University of Iceland, Árleyni 22, 112, Reykjavík, Iceland.

J.W. Bjerke. Norwegian Institute for Nature Research, FRAM - High North Research Centre for Climate and the Environment, Tromsø, Norway.

M.P. Björkman.* Department of Earth Sciences, University of Gothenburg, SE-405 30, Gothenburg, Sweden; Gothenburg Global Biodiversity Centre, SE-405 30, Gothenburg, Sweden.

D. Blok. Dutch Research Council (NWO), The Hague, The Netherlands.

G. Blume-Werry. Experimental Plant Ecology, Institute of Botany and Landscape Ecology, University of Greifswald, Soldmannstraße 15, Greifswald, 17487, Germany.

Corresponding author: Christian Rixen (e-mail: rixen@slf.ch).

${ }^{*}$ Gregory H.R. Henry served as a Consulting Editor, Ingibjörg S. Jónsdóttir served as an Associate Editor, and Christian Rixen, Mats P. Björkman, Signe Lett, and Alessandro Petraglia served as Guest Editors at the time of manuscript review and acceptance; peer review and editorial decisions regarding this manuscript were handled by Melissa Lafrenière.

${ }^{1}$ This paper is part of a Special Issue entitled: Impacts of climate change on tundra ecosystems: Three decades of results from the International Tundra Experiment (ITEX).

(C) 2022 The Author(s). This work is licensed under a Creative Commons Attribution 4.0 International License (CC BY 4.0), which permits unrestricted use, distribution, and reproduction in any medium, provided the original author(s) and source are credited.
} 
J. Boike. Alfred Wegener Institute, Helmholtz Centre for Polar and Marine Research, Telegrafenberg A45, Potsdam, 14473, Germany; Geography Department, Humboldt University of Berlin, Unter den Linden 6, Berlin, 10099, Germany.

M. Carbognani, T.G.W. Forte, and A. Petraglia.* Department of Chemistry, Life Sciences and Environmental Sustainability, University of Parma, Parco Area delle Scienze 11/A, I-43124, Parma, Italy.

C.T. Christiansen and S. Lett.* Terrestrial Ecology Section, Department of Biology, University of Copenhagen, Denmark. P. Convey. British Antarctic Survey, NERC, High Cross, Madingley Road, Cambridge CB3 OET, UK.

E.J. Cooper. Department of Arctic and Marine Biology, Faculty of Biosciences, Fisheries and Economics, UiT-The Arctic University of Norway, Tromsø N-9037, Norway.

S.J. Coulson. Department of Arctic Biology, University Centre in Svalbard, P.O. Box 156, Longyearbyen, Svalbard 9171, Norway.

E. Dorrepaal, F. Gehrmann, and J. Walz. Climate Impacts Research Centre, Department of Ecology and Environmental Science, Umeå University, Abisko, Sweden.

B. Elberling. Center for Permafrost (CENPERM), Department of Geosciences and Natural Resource Management, University of Copenhagen, Denmark.

S.C. Elmendorf. Institute of Arctic and Alpine Research, University of Colorado, Boulder. CO 80309-0450, USA.

C. Elphinstone. Department of Botany, University of British Columbia, 6270 University Blvd, Vancouver, BC V6T 1Z4, Canada.

E.R. Frei. WSL Institute for Snow and Avalanche Research SLF, Flüelastr. 11, Davos Dorf, 7260, Switzerland; Climate Change, Extremes and Natural Hazards in Alpine Regions Research Centre CERC, Davos Dorf, Switzerland; Department of Geography, University of British Columbia, Vancouver, BC V6T 1Z4, Canada; Swiss Federal Institute for Forest, Snow and Landscape Research WSL, Zuercherstrasse 111, Birmensdorf, 8903, Switzerland.

S.R. Geange. Department of Biological Sciences, University of Bergen, Bergen, Norway.

C. Gibson. School of Biological, Earth and Environmental Sciences UNSW, Sidney, Australia.

P. Grogan. Department of Biology, Queen's University, Kingston, ON K7L 3N6, Canada.

A.H. Halbritter, J.S. Lynn, and V. Vandvik. Department of Biological Sciences, University of Bergen, Bergen, Norway; Bjerknes Centre for Climate Research, University of Bergen, Bergen, Norway.

J. Harte. Energy and Resources Group, University of California, Berkeley, CA 94720, USA; Rocky Mountain Biological Laboratory, Crested Butte, CO 81224, USA.

G.H.R. Henry.* Department of Geography, University of British Columbia, Vancouver, BC V6T 1Z4, Canada.

D.W. Inouye. Department of Biology, University of Maryland, College Park, MD 20742, USA; Rocky Mountain Biological Laboratory, Crested Butte, CO 81224, USA.

R.E. Irwin. Rocky Mountain Biological Laboratory, Crested Butte, CO 81224, USA; Department of Applied Ecology, NC State University, Raleigh, NC 27695, USA.

G. Jespersen. Department of Biological Sciences, University of Alaska Anchorage, Anchorage, AK 99508, USA.

I.S. Jónsdóttir.* Life and Environmental Sciences, University of Iceland, Sturlugata 7, 102, Reykjavík, Iceland.

J.Y. Jung. Korea Polar Reseach Institute, Incheon, 21990, Republic of Korea.

D.H. Klinges. School of Natural Resources and Environment, University of Florida, Gainesville, FL 32611, USA.

G. Kudo. Faculty of Environmental Earth Science, Hokkaido University, Sapporo, 060-0810, Japan.

J. Lämsä and R. Paavola. Oulanka Research Station, University of Oulu, Liikasenvaarantie 134, Kuusamo, 93900, Finland.

H. Lee. NORCE Norwegian Research Centre, Bjekrnes Centre for Climate Research, Bergen, Norway.

J.J. Lembrechts. Research Group Plants and Ecosystems, University of Antwerp, Universiteitsplein 1, Wilrijk, 2610, Belgium.

M. Mastepanov. Oulanka Research Station, University of Oulu, Liikasenvaarantie 134, Kuusamo, 93900, Finland; Department of Bioscience, Aarhus University, Frederiksborgvej 399, Roskilde, 4000, Denmark.

J. Morse and K. Suding. Department of Ecology and Evolutionary Biology, and Institute of Arctic and Alpine Research, University of Colorado, Boulder, CO 80309, USA.

I.H. Myers-Smith. School of GeoSciences, The University of Edinburgh, Edinburgh, EH9 3FF, UK.

J. Olofsson and M.B. Siewert. Department of Ecology and Environmental Sciences, Umeå University, Umeå, SE-901 87, Sweden.

G.K. Phoenix. Department of Animal and Plant Sciences, University of Sheffield, Western Bank, Sheffield, S10 2TN, UK.

P. Semenchuk. Division of Conservation Biology, Vegetation Ecology and Landscape Ecology, Department of Botany and Biodiversity Research, Rennweg 14, 1030, Vienna.

M.J. Spasojevic. Department of Evolution, Ecology, and Organismal Biology, University of California Riverside, Riverside, CA 92521, USA.

P. Sullivan. Environment and Natural Resources Institute, University of Alaska Anchorage, Anchorage, AK 99508, USA.

K.L. Thompson. Department of Forest and Wildlife Ecology, University of Wisconsin - Madison, Madison, WI 53706, USA.

M. Väisänen. Ecology and Genetics Rresearch Unit, University of Oulu, Pentti Kaiteran street 1, Linnanmaa, Oulu 90014, Finland.

S. Venn. Centre for Integrative Ecology, Deakin University, 221 Burwood Hwy, Burwood, Victoria 3125, Australia.

R. Way. Northern Environmental Geoscience Laboratory, Department of Geography and Planning, Queen's University, Kingston, ON K7L 3N6, Canada.

J.M. Welker. Ecology and Genetics Rresearch Unit, University of Oulu, Pentti Kaiteran street 1, Linnanmaa, Oulu 90014, Finland; Department of Biological Sciences, University of Alaska Anchorage, Anchorage, AK 99508, USA; University of the Arctic (UArctic), Rovaniemi 96101, Finland.

S. Wipf. WSL Institute for Snow and Avalanche Research SLF, Flüelastr. 11, Davos Dorf, 7260, Switzerland; Swiss National Park, Chasté Planta-Wildenberg, Runatsch, 7530, Zernez.

S. Zong. Key Laboratory of Geographical Processes and Ecological Security in Changbai Mountains, Ministry of Education, School of Geographical Sciences, Northeast Normal University, Changchun, 130024, China. 


\begin{abstract}
Snow is an important driver of ecosystem processes in cold biomes. Snow accumulation determines ground temperature, light conditions, and moisture availability during winter. It also affects the growing season's start and end, and plant access to moisture and nutrients. Here, we review the current knowledge of the snow cover's role for vegetation, plant-animal interactions, permafrost conditions, microbial processes, and biogeochemical cycling. We also compare studies of natural snow gradients with snow experimental manipulation studies to assess time scale difference of these approaches. The number of tundra snow studies has increased considerably in recent years, yet we still lack a comprehensive overview of how altered snow conditions will affect these ecosystems. Specifically, we found a mismatch in the timing of snowmelt when comparing studies of natural snow gradients with snow manipulations. We found that snowmelt timing achieved by snow addition and snow removal manipulations (average 7.9 days advance and 5.5 days delay, respectively) were substantially lower than the temporal variation over natural spatial gradients within a given year (mean range 56 days) or among years (mean range 32 days). Differences between snow study approaches need to be accounted for when projecting snow dynamics and their impact on ecosystems in future climates.
\end{abstract}

Key words: review, tundra, ground temperatures, snow experiments, ITEX.

Résumé : La neige est un élément moteur important des processus écosystémiques dans les biomes froids. L'accumulation de neige détermine la température du sol, les conditions de luminosité et l'humidité disponible pendant l'hiver. Elle affecte également le début et la fin de la saison de croissance, ainsi que l'accès des plantes à l'humidité et aux nutriments. Les auteurs font ici une synthèse des connaissances actuelles sur le rôle de la couverture neigeuse pour la végétation, les interactions plantes-animaux, les conditions du pergélisol, les processus microbiens et l'établissement du cycle biogéochimique. Ils comparent également les études sur les gradients naturels de neige avec les études expérimentales de manipulation de la neige, afin d'évaluer la différence d'échelle temporelle de ces approches. Le nombre d'études sur la neige dans la toundra a considérablement augmenté ces dernières années, mais on ne dispose toujours pas d'une vue d'ensemble complète de la façon dont les conditions de neige modifiées affecteront ces écosystèmes. En particulier, ils ont trouvé un décalage dans le moment de la fonte des neiges en comparant les gradients spatiaux naturels de neige avec les manipulations de neige. Ils ont constaté que le moment de la fonte des neiges obtenu par les manipulations d'ajout et de déneigement (en moyenne 7,9 jours d'avance et 5,5 jours de retard, respectivement) était sensiblement inférieur à la variation temporelle sur les gradients spatiaux au cours d'une année donnée (plage moyenne 56 jours) ou entre les années (plage moyenne 32 jours). Les différences entre les approches d'étude de la neige doivent être prises en compte lors de la projection de la dynamique de la neige et de son impact sur les écosystèmes dans les climats futurs. [Traduit par la Rédaction]

Mots-clés : synthèse, toundra, températures au sol, expériences sur la neige, ITEX.

\title{
Introduction
}

In Arctic and alpine regions, snow and its specific properties such as depth, density, snow cover duration, and snow water equivalent plays a critical role for ecosystem processes across a wide range of temporal and spatial scales. Snowmelt timing, for example, may determine the beginning of the growing season and subsequent phenology and the growth responses of many organisms and growing season processes (Cooper 2014; Leffler et al. 2016; Kelsey et al. 2021). In addition, snow is a critical driver of soil temperatures (Pattison and Welker 2014), albedo and atmospheric temperature regimes, spring freshet meltwater inputs (Lopez-Moreno et al. 2014), and snow also influences decomposition rates and nutrient availability in the soil (Schimel et al. 2004; Brooks et al. 2011). 
Reviews over the past two decades have emphasized the importance of snow for cold climate ecosystems (Supplementary Table S2 ${ }^{2}$ ) beyond its importance as a driver of ecosystem processes: Jones et al. (2001) recognized snow as a complete ecosystem in itself with specialized organisms (e.g., Collembola and algae) living inside the snowpack (see also Körner 2003), whereas Kuhn (2001) addressed the snowpack's role in nutrient cycling. Since then, the importance of winter temperatures has been more widely recognized in Arctic and alpine (Callaghan and Johannson 2021) and boreal and temperate regions (Kreyling 2019). A main focus of recent reviews has been the changing duration of snow cover due to climate change, and its effects on ecosystem processes (Campbell et al. 2005; Brooks et al. 2011; Cooper 2014; Makoto et al. 2014; Kelsey et al. 2021) or society (Bokhorst et al. 2016b). Approaches to study snow cover changes though have been widely different (Jones et al. 1998; Welker et al. 2005b; Borner et al. 2008). However, even though the implications of snow cover changes on ecosystems may be heavily influenced by the methodology used, the differences between studies on natural snow gradients (spatially and temporally) and experimental manipulations has not been studied in detail.

A pioneering review and meta-analysis of snow manipulation experiments focusing on plant phenology analyzed 66 combinations of plant species and years clearly showed that flowering phenology (i.e., the timing of flowering), was linked to the timing of snowmelt (Wipf and Rixen 2010). The number of such experiments has increased considerably since then, and $20 \%$ of long-term (i.e., $>30$ years) climate change experiments in snow-covered systems include a snow manipulation treatment (Sanders-DeMott and Templer 2017). Most recently, Slatyer et al. (2021) reviewed 365 original research papers that used experimental field manipulations, natural snow gradients, and (or) long-term monitoring to test plant and animal responses at individual, population, and community levels to changes in snow conditions. Although they confirmed strong links between snow cover and ecological processes, they concluded that many mechanisms of how snow affects ecosystems, i.e., by changes in snow timing, depth, type, subsequent thermal insulation properties, nutrient availability or meltwater sources, etc., are not fully explored nor well understood.

Study types analysing natural snow gradients, i.e., gradients ranging from thin to deep snow cover due to topography, wind, etc., and those using experimental snow manipulations often focus on different primary questions, making comparisons challenging (Billings 1969; Elmendorf et al. 2015). Along natural gradients, studies can be performed over a longer time frame, with plants that are adapted to the local environment, yet snow conditions co-vary with other factors such as microtopography or vegetation structure (Walker et al. 1993). Experiments, by contrast, are designed for comparison with a specific control and, thus, are better suited to establish causal relationships (Rieley et al. 1995; Welker et al. 2005a; De Boeck et al. 2015; Yang et al. 2018). However, experimental treatments may introduce artefacts or simulate scenarios not necessarily in line with predictions under climate change. To better understand which research questions require specific attention, we present a review of studies that include natural snow gradients and (or) experimental snow manipulations, and demonstrate how these studies can collectively clarify the crucial role of snow cover in ecosystem processes. For this, we look at key snow variables with a focus on the timing of snowmelt, which can be derived from ground surface temperature data.

Specifically, we (1) summarize how snow depth and snowmelt timing in cold environments affect plants, animals, microbial processes, and biogeochemical cycling by updating the review by Wipf and Rixen (2010) to include studies published between 2010 and 2021 on

\footnotetext{
${ }^{2}$ Supplementary data are available with the article at https://doi.org/10.1139/as-2020-0058.
} 
snow and associated ecosystems; and (2) analyze soil temperature data from natural gradients of snowmelt timing (spatially and temporally) and from snow manipulation experiments (74 site-year combinations). We also assess whether such experiments change snowmelt timing realistically compared with natural spatial snow gradients and (or) interannual variability and trends in snowmelt timing.

\section{Direct effects of snow on ecosystems}

Snow accumulation affects ecosystems in both direct and indirect ways. Snow properties, like its volume, water/ice content, timing, and spatial distribution affect soil temperatures as well as light, water, and nutrient availability (Starr and Oberbauer 2003; Welker et al. 2005a; 2005b; Bintanja 2018; Convey et al. 2018; Jespersen et al. 2018). In the following section, we discuss the mechanisms by which different snow properties, in particular snow depth and density and snowmelt timing, affect the environment.

\section{Soil temperatures}

One of the key attributes of snow is how it acts as a thermal insulator and decouples soils from winter air temperatures, so that soil temperature fluctuations under snow are less than than air temperature fluctuations above the snowpack (Pruitt 1957; Goodrich 1982; Schimel et al. 2004; Schimel et al. 2006; Sullivan et al. 2008; Morgner et al. 2010; Zhang et al. 2018). Temperatures can remain very stable or even at $0{ }^{\circ} \mathrm{C}$ for extended periods under thicker snow covers (Haeberli 1973; Grundstein et al. 2005; Pattison and Welker 2014; Convey et al. 2018; Way and Lewkowicz 2018) and soils may be up to $5{ }^{\circ} \mathrm{C}$ warmer in the coldest period of winter, under deeper snow, for instance in northern Alaska (Pattison and Welker 2014). Haeberli (1973) found that a snow cover with a thickness of approximately $80 \mathrm{~cm}$ was sufficient to completely decouple the soil from air temperatures, although this threshold is dependent on the thermal conductivity, the density of the snowpack, and the onset of the snow accumulation (Riseborough, 2004). Relatively mild conditions at the soil surface, compared with air temperatures, under the snowpack have been described as a "greenhouse", accelerating soil microbial and other ecosystem processes (Cockell and Cordoba-Jabonero 2004; Cooper 2014). Both Way and Lewkowicz (2018) and Grünberg et al. (2020) found that snow depth and, most likely, snow structural differences, lead to pronounced differences in mean soil temperature, soil temperature variability, and timing of snowmelt across different vegetation types. Multiple field-based studies have found that the thermal impacts of variations in snow thickness over natural gradients can explain more of the spatial variability in ground temperatures than key climate variables such as mean annual air temperature (Granberg 1988; Davesne et al. 2017; Way and Lewkowicz 2018; Pelletier et al. 2019; Davis et al. 2020; Garibaldi et al. 2021; Kropp et al. 2021). Some modelling studies have shown that deeper snow thicknesses found particularly in tall vegetation may altogether prevent the formation of permafrost in regions that would otherwise be climatically suitable (Smith and Riseborough 2002; Tutton and Way 2021; Way and Lapalme 2021). In addition, the deeper snow in tall shrub communities are the landscape locations where winter $\mathrm{CO}_{2}$ emissions are found to be greatest, due to a combination of deeper snow and wetter conditions in riparian corridors. These water-tracks are winter $\mathrm{CO}_{2}$ hot spots across the North Slope of AK (Fahnestock et al. 1998). Although occupying smaller spatial scales, these water tracks can have winter $\mathrm{CO}_{2}$ emission rates that can be 2-3 times the rates of the surrounding, spatially extensive tussock tundra (Fahnestock et al. 1999a; Jones et al. 1999).

Many other studies show that taller vegetation can trap more snow and, hence, cause warmer ground temperatures leading to changes in numerous ecosystem processes (Sturm et al. 2001; Sturm et al. 2005b; Myers-Smith et al. 2011; Roy-Léveillée et al. 2014; 
Belke-Brea et al. 2020). With warming, tall shrubs have expanded (Myers-Smith et al. 2011; Ju and Masek 2016), which could result in a positive feedback loop of taller vegetation enhancing snow accumulation, which enhances shrubs (Sturm et al. 2001). However, this positive feedback may have limitations as climate warming progresses. Studies of early winter processes in the Low Arctic showed that snowmelt and refreezing can be more pronounced in tall vegetation, which increase the release of soil heat and, hence, accelerate its cooling (Barrere et al. 2018).

A recent study by Way and Lapalme (2021) used numerical model simulations and a meta analysis of vegetation effects on ground temperature to explore whether changes in vegetation and its subsequent influence on snow cover would lead to a net ground temperature warming or cooling effect. Their results suggested that the long-term effects of vegetation change on ground temperature would be strongly influenced by soil moisture characteristics but that changes to snow cover would likely dominate the ground thermal regime leading to a net warming effect.

Snow structural differences and soil moisture characteristics can affect physical snow properties such as density, thermal conductivity, and albedo (Sturm et al. 2005a; Flanner and Zender 2006; Domine et al. 2016). For instance, shrubs in the Canadian High Arctic were found to increase snow depth up to their maximum height (approximately $40 \mathrm{~cm}$ ), and to also change snow properties (Domine et al. 2016); snow density and thermal conductivity of snow were lower under shrubs. Also, depth hoar, which develops under large temperature gradients and is highly insulating (Colbeck 1983), grew up to shrub height, but only up to $5-10 \mathrm{~cm}$ in the absence of shrubs. Hence, shrubs increase the insulating properties of snow for several reasons. By contrast, Domine et al. (2016) also found that during times of snowmelt shrubs enhanced melting, e.g., through absorbed radiation, which reduced thermal resistance and, hence, counteracted the effects of shrubs detailed above. These examples illustrate the complex relationships between climate warming, plant cover, snow, and soil temperatures. Different processes also occur at different times of the year and are likely to impact soil temperatures, nutrient cycling, and also plant growth in the summer. These complex snow-climate-vegetation interactions require future research.

The timing of snow accumulation in autumn is crucial for the soil thermal regime in winter (Riseborough 2004; Jan and Painter 2020). Freezing temperatures prior to snow build-up result in colder soils during winter, whereas mild autumn air temperatures can lead to comparatively mild - or less cold - winter soil temperatures (Johansson et al. 2013; Lafrenière et al. 2013). By contrast, no or only a thin snow cover during the winter can cause soil cooling (previously described as "colder soils in a warmer world" in the context of climate change, Groffman et al. 2001; Davis et al. 2020). This has a profound effect on permafrost; for instance, in permafrost peatlands within the discontinuous and sporadic permafrost zones, wind redistribution of snowfall leads to shallow snow covers on elevated peat plateaus, which, in turn, promotes permafrost aggradation and persistence due to extensive soil heat loss during winter (e.g., Seppälä 1982; Way et al. 2018). By contrast, wind-blown snow accumulates in depressions across the landscape, insulating soil microbes, invertebrates, and plants from extreme cold temperatures (Convey et al. 2015; Convey et al. 2018; D'Imperio et al. 2018; Semenchuk et al. 2019). Thus, redistribution of snow within the landscape has the potential to accelerate or dampen permafrost thaw, which may impact and be impacted by vegetation greenness in the Arctic tundra (Wang et al. 2019).

In spring, deep snow usually promotes late snowmelt, which prevents solar radiation from reaching and heating the ground surface. This can lead to colder soils during the early growing season, delaying plant phenology and soil biogeochemical cycling (Convey et al. 
2018). However, when snowmelt is not delayed, the insulating effect of deep snow on soil thermal regimes in winter may carry over, resulting in higher soil temperatures and permafrost thaw in summer (Natali et al. 2019).

This winter effect on summer permafrost thaw has been shown in northern Alaska, where in an experimental deep snow zone, summer thaw was $25 \%$ greater compared with ambient snow areas (program by J. Welker, personal observation, 2020). Radiocarbon $\left({ }^{14} \mathrm{C}\right)$ analyses show that carbon emitted in summer in this experimental thermokarst area are derived from ancient $C$ (Nowinski et al. 2010; Blanc-Betes et al. 2016) and that this permafrost $\mathrm{C}$ may be emitted as $\mathrm{CO}_{2}$ and as $\mathrm{CH}_{4}$. Whether ancient $\mathrm{C}$ where permafrost is experimentally thawed (as a result of experimentally enhanced snow depth) is emitted in winter or in the shoulder seasons is, however, still uncertain, but new integrative $C$ capture techniques for ${ }^{14} \mathrm{C}$ analysis are proving useful for year-long studies of ancient $\mathrm{C}$ emissons in the Arctic (Pedron et al. 2021).

The timing of snowmelt is therefore a critical determinant for the legacy effects of winter snow regimes on the snow-free season (Wilcox et al. 2019). Changes in the depth of snow can have very different consequences for the energy balance of the ecosystem (Yoshino 1984; Klinges and Scheffers 2021) and for the ecology and activity of plants and soil microbes, depending on the timing of onset of snow accumulation in the autumn and the timing of snowmelt in the spring.

\section{Light}

Snow cover increases the albedo of the ground surface, reflecting much of the incoming solar radiation that could otherwise be absorbed by a darker ground or by photosynthetically active plant tissues (Liston et al. 2002). Hence, snow cover has a large influence on the energy budget of tundra ecosystems (Loranty et al. 2011). The magnitude of increase in albedo due to snow cover also depends on snow structure and the underlying surface composition, with tall-statured tundra vegetation showing lower albedo in snow-covered areas than low-statured vegetation or bare ground (Baker et al. 1991). For instance, in the study by Baker et al. (1991) 70\% albedo (a value estimated when most of the underlying surface is masked) was reached withapproximately $5 \mathrm{~cm}$ of snow on bare ground and withapproximately $15 \mathrm{~cm}$ in taller vegetation. Even with high albedo, light penetrates the snowpack. Measurements of solar radiation under different snow depths showed, for instance, that under $10 \mathrm{~cm}$ of snow a daily photon flux density of approximately $60 \%-80 \%$ compared with open sky solar radiation (Starr and Oberbauer 2003). Light extinction continued under deeper snow, and approximately $30 \%$ of light penetrated $20 \mathrm{~cm}$ and only $10 \%$ or less through $30 \mathrm{~cm}$ of snow (Starr and Oberbauer 2003), which can compare with a cloudy day. These values, of course, can vary considerably depending on physical properties and purity of the snow. Therefore, some plants, lichens, and microbes are able to photosynthesize while snow covered. For example, evergreen Arctic shrubs were found to photosynthesize under $30 \mathrm{~cm}$ of snow (Starr and Oberbauer 2003). Some plants, like the Australian Marsh Marigold (Caltha introloba F. Muell.), can even flower under snow, and the European Soldanella pusilla Baumg. pushes its flowers through the snow in spring. These findings highlight that important processes continue even in the presence of snow and indicate that the vegetation under snow is not necessarily dormant (Björk and Molau 2007).

\section{Meltwater from snow}

One important aspect of snow is the fate of meltwater and its role in aquatic ecology as it affects multiple physical, biological, and ecological processes. It is key to freeze-thaw processes in spring that create ground patterns including frost boils, soil stripes, and polygons (Hallet and Prestrud 1986; Kessler and Werner 2003; Walker et al. 2004; Horwath et al. 
2008). These physical influences of meltwater are complemented by differential frost heave, cryoturbation, frost boils, "polar stripe" landscapes and other permafrost landforms (Kessler and Werner 2003; Walker et al. 2004), which is reflected in the preferential growth of plants along patterns created by frost (Czimczik and Welker 2010). Furthermore, during spring melt the snowpack releases its content of nutrients and ions, with an early elution of water soluble species (e.g., Bales et al. 1989; Lilbaek and Pomeroy 2008; Björkman et al. 2014). With soil temperatures commonly close to zero and limited biological activity, most of these nutrients will flow on top of the soil to depressions or downstream ecosystems (Westergaard-Nielsen et al. 2020).

An illustrative example for the important role of meltwater is snowmelt timing in alpine and subalpine ecosystems in the Rocky Mountains. Summer rains usually arrive in July, terminating the typically dry period of May and June. As a result, the timing of meltwater release from the winter snowpack can be a critical factor shaping the composition of vegetation communities. Evidence for this comes from a 29-year experimental warming study at the Rocky Mountain Biological Laboratory (RMBL) in Colorado, USA (Harte et al. 1995). At the start of the experiment 30 years ago, meltwater release typically peaked in early June and, thus, there was sufficient soil moisture for the vegetation through the low precipitation months of June and early July. But in the experimentally heated plots and, in recent years even in the control plots, melting occurred already in March or April. By mid-May, the meltwater had run through the system, leaving much drier soils until the summer monsoonal precipitation events arrived. The drought stress from this lengthened dry interval had caused a dramatic shift from a forb-dominated vegetation to shrubs such as sagebrush. This vegetation shift resulting from a changing spring water regime was especially strong in the warmed plots, yet could even be observed in the control plots in more recent years (Harte et al. 2015; Harte 2019).

Links between meltwater and ecosystem processes have been further extended recently into the ecophysiology and ecohydrology of tundra and boreal plants (Jespersen et al. 2018). It is clear that meltwater and the ionic pulse it carries are a key source of moisture and nutrients for tundra plants (Buckeridge and Grogan 2010). Just as important, this source of moisture appears to cause an extension of late-season high rates of leaf-level photosynthesis, linking meltwater to ecosystem $C$ fixation and influencing annual tundra $C$ fluxes and C source-sink attributes (Leffler et al. 2016; Wieder et al. 2017). Further evidence of snow meltwater as a key source of water that leads to changes in C cycling processes is provided by Welker et al. (2005b). This study shows that for years in which snow pack is deeper, snow meltwater is apparent $\left(\delta^{18} \mathrm{O}\right.$ values) in the growth segments of Cassiope tetragona (L.) D. Don that correspond with increases in leaf $C$ isotope discrimination $\left(\delta^{13} \mathrm{C}\right.$ values) associated with greater degrees of leaf $C$ fixation.

Knowledge concerning the complex dynamics between snow, snowmelt, hydrology, nutrient availability, plant growth, and ecosystem dynamics has expanded significantly over the past 10-15 years using a host of new tools, incuding water isotope forensics (Welker et al. 2000; Jespersen et al. 2018) and remote sensing tools (Kelsey et al. 2021). Yet, new studies are needed to fully resolve all connections between changes in snow and the function and structure of tundra vegetation and subsequent effects on herbivores that depend on these landscapes (Pedersen et al. 2021; Richert et al. 2021).

\section{Ecosystem responses to snow and climate change}

Ongoing climate change can have a considerable influence on snow distribution patterns, snow redistribution, snow drift formation, and compaction as part of the general snowpack development as well as snow duration and depth (Bokhorst et al. 2016b). These processes are directly linked to natural variation in wind regimes and fluctuating air 
temperatures with implication for the thermal impacts of snow cover (Gisnås et al. 2016; Davesne et al. 2017). With increased warming, many areas have recorded a reduction in the duration and amount of snow during recent decades (Marty 2008; Bormann et al. 2018; Klein et al. 2018; Pulliainen et al. 2020). For example, the snow cover duration in Switzerland has decreased by 8.9 days per decade (Klein et al. 2016). Other areas, however, have experienced increased winter snow precipitation, which might, to some extent, compensate for warming-related snow reduction (Trenberth 2011; Notaro et al. 2014; Notaro et al. 2015). Changes in the distribution and duration of snow cover and their effects on ecosystems may vary significantly on local and regional scales (Cooper 2014). Less snow in winter may lead to decreased insulation and subsequently colder soils (see above, and Zhang et al. 2008). More snow in winter, by contrast, generally has the opposite effect and causes warmer winter soils (Goodrich 1982; Schimel et al. 2004; Zhang 2005; Morgner et al. 2010; Pattison and Welker 2014; Zhang et al. 2018).

With warming, periods of above-zero temperature during winter become more likely, which can create ground ice layers. Rain-on-snow (ROS) events could also become more frequent, potentially leading to the formation of both ice lenses in the snow pack and on the ground with major consequences to ungulates and the forage they consume (Hansen et al. 2014; Beniston and Stoffel 2016; Hansen et al. 2019). In addition, ROS events are predicted to increase the risk of avalanche events and flooding, or of extensive ground ice formation in the High Arctic (Vikhamar-Schuler et al. 2016). In addition, modelling studies have shown that large rain events could create warming effects on soil (Putkonen and Roe 2003) and accelerated permafrost degradation (Westermann et al. 2011). Ground ice formation can lead to deleterious effects on the biota, ranging from soil microarthropods (Coulson et al. 2000), evergreen dwarf shrubs (Milner et al. 2016), and vertebrates (Hansen et al. 2013) and affect plant phenology and reproduction (Le Moullec et al. 2019). Below, we review the effects of snow changes on plants, trophic interactions, plant pathogens, and winter biogeochemical processes.

\section{Plant phenology, growth, and communities}

Plant above-ground phenology, growth, and community composition are very tightly linked to the distribution and timing of snow (Tranquillini 1982; Sakai and Larcher 1987; Semenchuk et al. 2016b; Assmann et al. 2019). Snowmelt has been found to be a better predictor of tundra plant phenology dynamics than local temperatures (Assmann et al. 2019), and increasing snowfall and resulting snowmelt dynamics have been attributed as a reason for a lack of phenological change over time at some tundra sites (Bjorkman et al. 2015). Snowmelt timing is additionally strongly associated with snowbed species (Cooper et al. 2011; Semenchuk et al. 2016b), as snowmelt is often late in the season, and the remaining time for flowering and fruiting is thus very short, i.e., sometimes only a few weeks (Venn and Morgan 2007; Hülber et al. 2010; Wipf 2010; Carbognani et al. 2016; Kudo and Cooper 2019). Some species can emerge through a thin snow cover with their flowers (e.g., Soldanella pusilla Baumg.) to advance the beginning of the growing season by a few days (Körner et al. 2019; Rixen 2020). Plants from ridges with little snow cover, by contrast, potentially have a longer growing season, but risk freezing damage when flowering and loss of winter frost resistance too early (Rixen et al. 2012; Venn et al. 2013). The phenology of many alpine plants is, therefore, often limited by photoperiod, and development only starts when days are long enough and the risk of freezing events is low (Keller and Körner 2003).

Plant species with no photoperiod limitation may need snow cover as protection from freezing (e.g., the evergreen shrub Rhododendron ferrugineum L.) and can suffer from freezing damage if snow cover is not sufficient (Larcher and Siegwolf 1985). Conversely, experimentally deepened snow may have positive effects, e.g., it can lead to substantial Rhododendron 
subarcticum Harmaja growth, as the species' favoured microclimate conditions are prolonged in late winter and early spring when competing species remain dormant (Christiansen et al. 2018a). Deeper snow cover can also protect the overwintering preformed flower buds from frost damage as a result of cold winter air temperatures; this is particularly evident from the damage done to buds during winters with little snow or extreme events in which mild periods (often accompanied by rain) melt away snow cover, followed by a return to freezing air temperatures (Semenchuk et al. 2013). In addition, extreme winter events that result in damaging snow conditions for plants can also delay spring phenology and reduce flowering (Le Moullec et al. 2019). For instance, extreme winter warming and associated loss of mid-winter snow resulted in delayed bud burst of the dwarf shrub Vaccinium myrtillus L. by up to three weeks in the following spring, although other species were less affected (Bokhorst et al. 2008). By contrast, experimental winter ice encasement (ROS simulation) caused earlier spring bud-burst in the same species (Preece et al. 2012). However, responses to extreme winter events appear species-specific and work is needed to further identify vulnerable/resistant groups and the mechanisms involved (Bokhorst et al. 2010a; Bokhorst et al. 2018; Le Moullec et al. 2019).

Variation in snowmelt timing not only leads to variation in the timing of phenological events, but also in the duration of developmental stages, which suggests different strategies of plants for responding to snowmelt timing (Semenchuk et al. 2016b; Gehrmann et al. 2017). Across all plant species in tundra ecosystems, however, most studies have reported advancing phenological development with climate warming and decreasing snow cover both in experiments (Wipf and Rixen 2010; Bjorkman et al. 2015; Rosa et al. 2015; Assmann et al. 2019; Jabis et al. 2020b; Collins et al. 2021) and in long-term monitoring (Wolkovich et al. 2012). In a global comparison, the phenology of plant populations from colder regions (High Arctic) was more sensitive to temperature than that of populations from warmer regions (Low Arctic) (Prevey et al. 2017; Prevey et al. 2019), which indicates that different plant species and populations from different regions can vary in their phenological response to climate and snow cover change.

Modifications of phenologies may disturb mutualistic interactions between species, i.e., phenological mismatch (see trophic interactions below; Memmott et al. 2007; Hegland et al. 2009; Green 2010; Forrest 2015). In studies along snowmelt gradients, changes in flowering phenology strongly affected the seed set and outcrossing rate of alpine plants visited by bumble bees (Kameyama and Kudo 2009; Kudo et al. 2011; Moriwaki et al. 2020). Therefore, phenological changes are also likely to affect interactions between flowers and pollinators (McKinney et al. 2012; Høye et al. 2013; Kudo and Ida 2013; Gillespie et al. 2016; Ogilvie et al. 2017; Robinson and Henry 2018; Kudo and Cooper 2019). For example, a study of bee pollinators in the subalpine found that their emergence, peak, and senescence phenology respond to snowmelt timing, but their rate of response is less sensitive than that of flowers (Stemkovski et al. 2020), creating the potential for reduced synchrony between bees and their flowers with earlier snowmelt timing.

Although aboveground phenological responses to earlier or later snowmelt have been greatly expanded with the coupling of vegetation and snow remote sensing (Kelsey et al. 2021), much less is known about belowground root phenology and its interaction with the timing of snowmelt. A few studies do suggest, however, that root phenology may be much less responsive than aboveground responses, as it did not change with increased snow depth (and later snowmelt) in a wetland in Greenland (D'Imperio et al. 2018), nor with an earlier snowmelt in heath and meadow communities in the Swedish sub-Arctic (BlumeWerry et al. 2017). Makoto et al. (2014) showed for woody seedlings from Japanese forests with substantial winter snow cover that spring root and shoot growth phenology were decoupled across multiple species while they were coupled at the end of the growing 
season. Thus, root phenology cannot simply be inferred from aboveground phenology (Abramoff and Finzi 2015; Blume-Werry et al. 2016; Schwieger et al. 2018).

Tundra plant growth corresponds with growing season length and soil moisture availability in tundra ecosystems (Myers-Smith et al. 2015; Ackerman et al. 2017), although some species of High Arctic plants are periodic and stop growth after a set amount of time or thawing degree days (Starr et al. 2000; Rumpf et al. 2014; Semenchuk et al. 2016b). Tundra shrub growth dynamics and the climate sensitivity of shrub growth is highly variable among species and sites (Dawes et al. 2011; Myers-Smith et al. 2015) and potential key climate drivers are both direct (e.g., snow melt timing, frost damage, snowmelt hydrology, etc.) and indirect (e.g., altered nutrient availability, accelerated permafrost thaw, etc.) (Myers-Smith et al. 2019). Dendroecology studies have found greater temperature sensitivity of tundra shrubs in wetter versus drier sites (Elmendorf et al. 2012; Myers-Smith et al. 2015; Ackerman et al. 2017) and the site-level soil moisture status is in part controlled by snowmelt dynamics (Westergaard-Nielsen et al. 2020). Deeper snow has been found to promote R. subarcticum shrub growth in Arctic tundra (Christiansen et al. 2018a, see above), while longer growing seasons have been found to promote $R$. ferrugineum shrub growth in alpine tundra (Francon et al. 2020). Both species grow in areas with long snow cover, but the seemingly contradictory results highlight the complexity in capturing responses of tundra plant growth to interacting climate drivers.

The patterns of plant community distributions strongly match those of the mean timing of snowmelt in heterogeneous landscapes (Friedel 1961; Körner 2003). In studies along snowmelt gradients, grasses and other tall and productive species encroached into snowbeds only a few years after snowmelt started to advance (Green and Pickering 2009; Pickering et al. 2014; Venn et al. 2014). With ongoing climate change, this could result, in the long term, in a reduction of habitat for snowbed specialists and a resultant decrease in biodiversity (Niittynen et al. 2018) as more competitive species encroach into these historically late-lying snow areas (Williams et al. 2015). Expansion of shrubs and graminoids is common in snow meadow and snowbed habitats with climate change (e.g., Wipf et al. 2009; Spasojevic et al. 2013; Formica et al. 2014; Myers-Smith et al. 2019). Comparisons of community structure in snow meadows revealed that the mosaic patterning of alpine vegetation has become obscured during the last 40 years and that the structure of alpine vegetation has become more uniform due to accelerated snowmelt and drier soil conditions linked to global warming (Amagai et al. 2018).

\section{Trophic interactions}

Snow plays a vital role in the ontogeny and population dynamics of many animals (Korslund and Steen 2006; Bale and Hayward 2010), and has been proposed as one of the main climatic factors affecting trophic interactions in tundra ecosystems (Berg et al. 2008; Berteaux et al. 2017). For example, the timing and intensity of herbivory varies between habitats of contrasting snow cover (Speed et al. 2009; Anderson et al. 2016b), and the snow sensitivity of tundra herbivore emergence and migration in turn influences higher trophic levels (Maclean and Pitelka 1971; Tulp and Schekkerman 2008). Climate-induced alterations in snow conditions will thus undoubtedly affect the interactions between plants and their herbivores, with consequences for other trophic levels.

Snow conditions, including spatial patterns, the onset and duration of winter snow cover, and thawing events during winter can influence plant-herbivore-predator interactions in a number of ways. First, snow distribution directly affects food accessibility to herbivores, which will influence their distribution (Berg et al. 2008; Pedersen et al. 2021). For example, during winter, muskoxen and reindeer/caribou prefer areas with thin snow cover where food is more easily accessible (Schaefer and Messier 1995; Riseth et al. 2011; 
Pedersen et al. 2021), whereas lemmings favour areas with deeper and more persistent snowpack that protects them from temperature extremes and predators (Gilg et al. 2009; Duchesne et al. 2011; Reid et al. 2012). Which habitats become available (snow-free) earlier in the season will also affect the spatial distribution of herbivores and their population dynamics (Layton-Matthews et al. 2020). For example, during the spring pre-breeding period prolonged snow cover restricts access of pink-footed geese (Anser brachyrhynchus Baillon, 1834) to their preferred foraging habitat on wet areas (Anderson et al. 2012; Pedersen et al. 2013).

In turn, snow provides plants with a physical barrier against some herbivores. For example, during winter, ptarmigan and hares have a limited ability to dig into the snow and, thus, forage primarily on plants emerging through the snowpack or growing in wind-blown areas (Hakkarainen et al. 2007; Tape et al. 2010). In High Arctic Greenland, Arctic hare and rock ptarmigan benefit from muskox opening the snowpack (Schmidt et al. 2018). A similar phenomenon has been observed in Svalbard, where reindeer cratering opens up foraging areas for rock ptarmigan (Pedersen et al. 2006). Conversely, plants are better protected from small mammal herbivory in areas with shallow snow, as small mammals will concentrate in areas with deeper snow in winter (Duchesne et al. 2011). Large herds of reindeer, caribou, and muskoxen are not only affected by snow, but have direct impacts on snow properties; trampling on snow alter snow depth and density, and hence also winter soil temperatures, with cascading effects on summer soil temperatures (Roturier and Roué 2009; Riseth et al. 2011).

The timing of snowmelt is also one of the most important predictors of the phenology and activity of arthropods in the High Arctic (Høye and Forchhammer 2008; Coulson et al. 2014), although the responses seem to be group specific (Dollery et al. 2006; Kankaanpää et al. 2018). Some studies have found increased invertebrate herbivory in earlier snowmelt areas (Roy et al. 2004; Berg et al. 2008; Little et al. 2016; Wheeler et al. 2016), but others have reported increased levels of herbivory in those areas characterized by late snowmelt (Torp et al. 2010a, 2010b). Late snowmelt can increase plant palatability to herbivores by altering plant chemistry (Walsh et al. 1997; Semenchuk et al. 2015; Mörsdorf et al. 2019). In a snow fence experiment, the growth of moth larvae was higher when fed on leaves from the snow fence plots, suggesting that later snowmelt enhanced food quality for these herbivores (Torp et al. 2010a). Similarly, other studies have found that invertebrate herbivores like aphids and scale insects (Coccoidea) were most numerous in late snowmelt plots (Høye and Forchhammer 2008).

Finally, thawing events during winter and ROS events can create ice crusts within the snowpack or ground ice, and episodes of heavy rain can cause flooding in the subnivean space and subsequent formation of a thick layer of ground ice (Hansen et al. 2014). Such ice layers prevent access to food by herbivores (Hansen et al. 2013), resulting in increased mortality and reduced fecundity. As an example, large ROS events in Yamal, Russia caused heavy mortality of reindeer (Sokolov et al. 2015; Forbes et al. 2016), with subsequent impacts across trophic levels causing increases of generalist predators (Sokolov et al. 2015). The occurrence of ROS events in the autumn determines the hardness of the basal snow layer and negatively influences brown lemming demographic parameters (Domine et al. 2018). The formation of ground ice can also lead to anoxia in the plant-soil interface and in the soil beneath, resulting in increased damage to, or mortality of plants (Bjerke et al. 2017), lichens (Bjerke et al. 2011), and soil invertebrate communities (Coulson et al. 2000) and, hence, decomposition and nutrient cycling processes (see below).

Climate change may have different consequences for different plant-herbivore systems, depending on the relative effects of temperature, snow, and precipitation, and the frequency and strength of climate related extreme events. Changes in snow patterns can affect herbivores in species-specific ways (Berteaux et al. 2017). Some herbivores, such as small 
mammals who actually live and reproduce under the snow, could be negatively affected by longer snow-free periods when predation risk is higher, whereas large herbivores that are less vulnerable to predation could potentially benefit from longer snow-free periods due to longer food accessibility (Berg et al. 2008). Changing snow conditions associated with climate warming have been proposed as a potential cause for the dampening of population cycles of small mammals (Domine et al. 2018), possibly due to increased cold stress when snow cover and depth are reduced (Kearney 2020) although the underlying mechanisms may differ across study locations (Kausrud et al. 2008; Gilg et al. 2009).

\section{Fungal pathogens}

Snow molds are an important group of fungal pathogens that have a particularly clear relationship with snow cover (Smith et al. 1989). Snow molds are a taxonomically diverse group of fungi that occur throughout the Arctic tundra and attack overwintering plants under snow (Hsiang et al. 1999; Matsumoto 2009). Evergreen dwarf shrubs (Olofsson et al. 2011) and mosses (Moriana-Armendariz et al. 2021) are likely to be hit hardest by these pathogens as their growth form implies the presence of exposed green leaves under the snow. However, there are also snow molds that attack plants from other functional groups, such as grasses or trees at the treeline (Barbeito et al. 2012; Barbeito et al. 2013). Snow molds require snow cover to spread to new host plants and are often favoured by deep snow, as deeper snow cover usually results in warmer and more moist conditions, which are optimal for their spread (Snider et al. 2000; Matsumoto 2009). Outbreaks of snow molds are common during years with deep long-lasting snow cover and have considerable consequences for ecosystems, such as "winterkill" of plants (Matsumoto 2009). Snow molds are, thus, expected to increase in abundance and importance where future climate change results in deeper snow cover and warmer temperatures.

Fungal pathogens can even outweigh beneficial effects of snow cover changes to plants. For example, although plant growth may be increased by the warmer temperatures under a thicker winter snow cover, it may also facilitate outbreaks of parasitic fungi (Olofsson et al. 2011; Moriana-Armendariz et al. 2021). In northern Sweden, the evergreen shrub Empetrum hermaphroditum Lange ex Hagerup experienced a fungal outbreak of the pathogen Arwidssonia empetri (Rehm) B. Erikss. that killed the majority of the plants and led to a reduction in net ecosystem carbon exchange during the growing season (Olofsson et al. 2011). Response of parasitic fungi to snow enhancement may, thus, contribute to the observed changes in vegetation composition (Cooper et al. 2019).

Snow distribution can also influence the effects of fungal pathogens by altering host plant abundance and susceptibility, or by influencing the spread of the pathogen (Matsumoto 2009). Thus, the effect of snow on pathogens will vary depending on traits of the host plants and the pathogens. Direct effects of snow on pathogens are expected to be mainly negative as fungi require high humidity conditions for spore dispersal, germination and infection. However, the effects on host plant abundance and susceptibility could range from positive to negative, and override the effects on pathogen spreading (Roy et al. 2004).

\section{Winter biogeochemical processes}

The most important control of winter soil microbial activity and biogeochemical cycling in cold regions is liquid water availability (Mikan et al. 2002; Brooks et al. 2011). Frozen soil water hinders diffusion of substrates and enzymes, effectively limiting microbial activity (Öquist et al. 2009). However, even when soils freeze, liquid water persists as unfrozen films around soil particles, particularly when temperatures remain above -5 to $-10{ }^{\circ} \mathrm{C}$. Consequently, snow accumulation is critically important for facilitating winter microbial activity and biogeochemical cycling in Arctic and alpine environments. 
Continued soil organic matter decomposition during winter (Schimel et al. 2004; Schimel et al. 2006) results in significant emissions of $\mathrm{CO}_{2}$ through the snow pack (e.g., Oechel et al. 1997; Fahnestock et al. 1999b; Grogan and Jonasson 2005; Sullivan et al. 2008; Euskirchen et al. 2012; Natali et al. 2019). Despite low absolute emission rates compared with summer, these winter emissions may accumulate to large magnitudes, as winter snow cover may be present for up to $75 \%$ of the year. As a result, cumulative winter $\mathrm{CO}_{2}$ emissions are often greater than summer plant $C$ uptake, and tundra ecosystems are now increasingly becoming net $\mathrm{CO}_{2}$ sources on an annual basis (Belshe et al. 2013; Euskirchen et al. 2017; Natali et al. 2019). For instance, the current loss of carbon during the winter season from October to April amounted to $1622 \mathrm{Tg} C$ per year for the entire permafrost regions, which is considerably more than the estimated carbon uptake of $1032 \mathrm{Tg} C$ during the growing season (Natali et al. 2019). These winter $\mathrm{C}$ emissions are even predicted to increase by $17 \%$ under a moderate mitigation scenario (Natali et al. 2019). Although many models project increased snowfall for the Arctic in coming decades, there are still large uncertainties, including interannual variation and regional differences and shifts to increased rain, associated with future snowfall regimes (Callaghan et al. 2011; Bintanja 2018). Nevertheless, warmer winters with increased snowfall and earlier spring snowmelt date are expected for most regions, and these changes in winter climate are very likely to increase wintertime $\mathrm{CO}_{2}$-release from Arctic landscapes (Natali et al. 2019). With ongoing climate change, the magnitudes and patterns of net $C$ emissions depend on different aspects of timing and depth of snow cover, which may affect these $C$ source-sink relations in several ways. Although it is generally expected that warmer soils in winter will lead to greater microbial respiration and greater winter $C$ efflux, several recent studies have pointed to important complexities in the relationship between winter soil temperature and microbial respiration. For instance, experimental studies in the subalpine forest and near the southern limit of Arctic tundra have shown that soil microbes can exhaust the supply of labile $C$ during warm winters and (or) beneath deep insulative snowpacks, with important implications for both winter and summer $\mathrm{CO}_{2}$ emissions and soil nutrient cycling (Brooks et al. 2005; Sullivan et al. 2020). Indeed, deeper snow increased wintertime $\mathrm{CO}_{2}$ release in distinct Canadian and Svalbard tundra sites (Nobrega and Grogan 2007; Semenchuk et al. 2016a), leading to reduced soil C storage (Semenchuk et al. 2019) and ultimately lower summertime $\mathrm{CO}_{2}$ release after 5-10 years (Semenchuk et al. 2016a; Christiansen et al. 2018a). Consequently, it seems clear that changes in winter climate will not only affect non-growing season carbon fluxes, as legacy effects also carry over to determine ecosystem carbon balance in summer.

Over the long term, deeper snow may reduce soil cooling in winter, resulting in thawing permafrost and a deeper active layer in summer that facilitates emission of ancient labile permafrost $C$ to the atmosphere (Czimczik and Welker 2010; Natali et al. 2014; Natali et al. 2015). These factors all play an important role in driving whether, and to what extent, we can expect soil C losses in the Arctic (Crowther et al. 2016; Crowther et al. 2018; van Gestel et al. 2018).

Along with enhanced winter-long soil $\mathrm{C}$ mineralization and $\mathrm{CO}_{2}$ emissions, deeper snow leads to increased mineralization of nutrients, such as nitrogen and phosphorus (Schimel et al. 2004; Schimel et al. 2006; Rixen et al. 2008; Buckeridge et al. 2013; Mörsdorf et al. 2019; Xu et al. 2021), resulting in an annual microbial biomass peak in late winter (Buckeridge et al. 2013). Following snowmelt, enhanced nutrient supply from winter nutrient mineralization and lysing microbes can manifest during the growing season as higher tundra plant leaf $\mathrm{N}$ and P concentrations (Welker et al. 2005a; Semenchuk et al. 2015; Mörsdorf et al. 2019). These leaf nutrient concentrations are important as they contribute to leaf-level photosynthesis which, when considered at the plant community level, can 
influence $C$ sequestration during summer (Pattison and Welker 2014). However, whether the net effect of summer $\mathrm{C}$ fixation in a warmer climate will exceed winter-long $\mathrm{CO}_{2}$ emissions is still not fully resolved (Welker et al. 2000; Natali et al. 2019).

The temporal patterns of snowmelt in spring may either open the tundra to spring warmth when snow melts earlier, leading to early leaf out and rapid $C$ gain, or delay snowmelt and thus the onset of spring growth, thereby prolonging snow-covered $\mathrm{CO}_{2}$ emissions through a delayed snowmelt of deeper winter snow. These complexities and the net effect of deeper or shallower snowpack, earlier or later onset of snow cover in autumn and snow melt in spring will all affect the future $C$ budget, with the integrated effect of these changes having either a positive or negative climate feedback effect (Welker et al. 1997; Oberbauer et al. 1998; Starr et al. 2000; Starr et al. 2008; Steltzer et al. 2009; Grogan 2012; Livensperger et al. 2016; Darrouzet-Nardi et al. 2019).

An important aspect of climate change effects on biogeochemical processes is the occurrence of extreme events in winter (see above). Extreme winter warming events associated with loss of snow, frost drought or ice layer development can cause plant damage and mortality and lead to substantial reductions in gross primary productivity (GPP) (Bokhorst et al. 2009). They can also lead to reduced ecosystem respiration as a result of the lower GPP, with a net effect of an overall reduction in ecosystem carbon sequestration (net primary productivity) in the following growing season (Treharne et al. 2019; Treharne et al. 2020).

Although below-ground soil organic matter decomposition rates increase with enhanced snowfall and accumulation (see above), the effects of warmer winter temperatures on foliar litter decay rates on the ground surface seem variable. Recent experimental studies in diverse tundra landscapes across the circumpolar Arctic suggest that deeper snow alone has a negligible effect on litter mass loss (Walker et al. 1999; Aerts et al. 2012; Myers-Smith and Hik 2013; DeMarco et al. 2014; Christiansen et al. 2017; Christiansen et al. 2018b), although alpine snow gradient studies showed positive relationships between snow depth (Saccone et al. 2013) or snow-cover duration (Carbognani et al. 2014) and litter decomposition. Experimental snow reduction, however, showed negligible effects on litter decay rates (Bokhorst et al. 2013b), suggesting that changes in winter microclimate may have little impact on the litter layer. This apparent site- and year-dependent discrepancy between ground surface and belowground soil microbial activities in winter could be due to more pronounced frost desiccation and, therefore, unfrozen water limitation of the surface litter layer relative to soil organic matter. Although there is still uncertainty on the responsiveness of the decomposers and physical breakdown of leaf litter material during winter and the role snow plays in this process (Hobbie and Chapin 1996; Bokhorst et al. 2010b; Bokhorst et al. 2013b), it appears that snow accumulation by itself has little impact on mid-winter litter mass losses, when temperatures are well below freezing. However, where changes in snow cover cause community change (see below), this may lead to changes in litter quality and thereby decomposability. For instance, an experimental study on tundra biome litter decomposability indicated that a change from herbaceous to shrub-dominated tundra would lead to lower litter decomposability (Cornelissen et al. 2007). How changes in litter quality and overall microbial decomposition rates as induced by changes in snow cover, in combination, lead to changing litter decomposition rates is a question in need of in-depth study.

\section{Studying effects of snow changes on ecosystems}

Given the critical role of snow cover in numerous ecosystem processes and the disruption to prevailing patterns of snow cover predicted under climate change, many studies have investigated the various effects of changing snow parameters (e.g. snow duration, depth and quality) on ecosystems (e.g., Rixen et al. 2004), as well snow-related extreme 
Fig. 1. Map of studies used in our analysis. Yellow dots indicate a snow manipulation experiment, green triangles indicate studies along a natural snow gradient (i.e., plots within a given region with different amounts of snow due to topography). The snow classification and the shape files for projecting these layers follows Sturm et al. (1995) and the Atlas of the Cryosphere (Maurer 2007), where darkest blue to lightest blue colours, in order, represent ice, alpine, prarie, maritime, taiga, and tundra. Some regions with seasonal snow, primarily in the Southern Hemisphere, do not have a classification according to the system of Sturm et al. (1995). The base map was produced in R using the "ggplot2" R package (Wickham 2016) to project a 2013 world map that is freely available from the Natural Earth project (https://www.naturalearthdata.com/, 1:50 m scale, no permission for reuse required). The map and the snow classification layers were projected using a WGS84 geographic coordinate system from the "raster" R package (Hijmans 2021), which aligned coordinates from the map and snow layers with the GPS coordinates of the study locations.

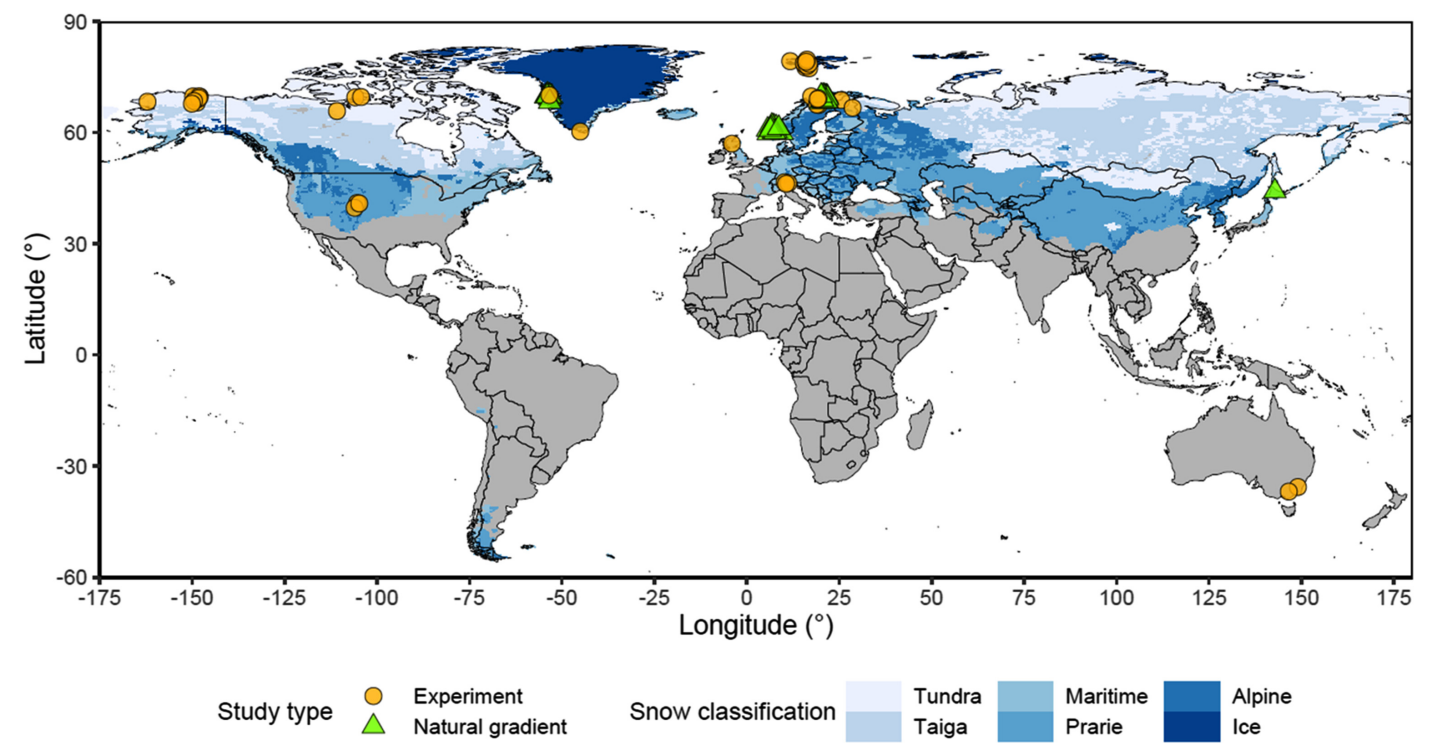

events such as icing (Coulson et al. 2000; Preece et al. 2012; Hansen et al. 2014) and extreme winter warming (Bokhorst et al. 2008; Bokhorst et al. 2011a). Here, we review two types of snow studies: those that aim to understand natural gradients and those that manipulate snow depth experimentally. To contrast snow manipulation experiments with natural snow gradient studies, we gathered temperature data from snow studies (74 site-year combinations of manipulations and natural gradients) to analyze and compare timing of snowmelt (defined as end of the zero degree curtain, i.e., the increase in temperature after disappearance of snow) (Figs. 1 and 2; methods in Supplementary Material $1^{2}$ ). We also consider the seasonal setting of snow studies, in order to account for studies being carried out at sites with naturally early, mid or late snowmelt.

\section{Remote sensing approaches}

A promising approach to quantifying natural gradients of snow cover over different and large spatio-temporal scales is to use remote sensing data from satellites, drones, and other types of photographic data (Malnes et al. 2016; Kankaanpää et al. 2018). Satellite snow products, such as simulated potential snow accumulation patterns (Randin et al. 2009), first snow-free day (Dedieu et al. 2016), and snow cover duration (Niittynen et al. 2018), demonstrate the importance of snow cover in explaining vegetation composition, distribution, and phenology in cold biomes (Walker et al. 1993; Zeng and Jia 2013; Kelsey et al. 2021). However, as many Arctic ecosystem properties are scale-dependent (Siewert 2018; Assmann et al. 2020; Siewert and Olofsson 2020), the spatial resolution of satellite-based 
Fig. 2. Most snow manipulation experiments change the snowmelt date by less than what can be observed due to variation in space or time (Fig. 3). Treatment $\times$ year combinations are ordered by site day of snowmelt (i.e., day of year for sites from the Northern Hemisphere and day of year - 182 for sites from the Southern Hemisphere) first per site, then by year within site. The type of snow manipulation is indicated for each site/experiment. All experiments with snow addition only (represented only by green and red dots) were realized by snow fences. All experiments that included snow removal or included exclusively snow removal (represented by a blue dot) were carried out by snow shoveling (except for USA Niwot Ridge, marked with an asterisk, where black sand was used to advance snowmelt).

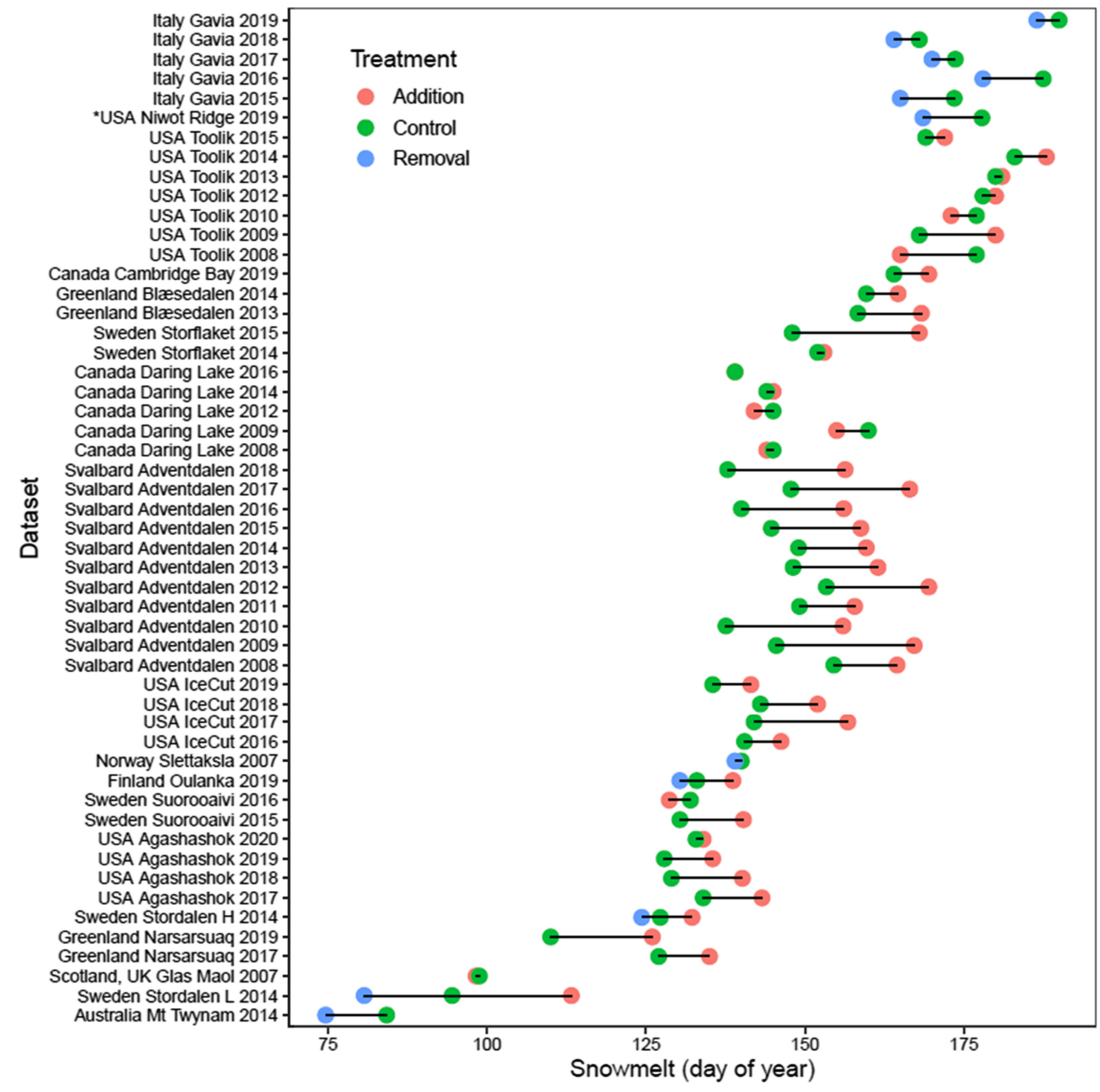

remote sensing approaches with a coarse resolution (e.g., 30-500 m pixel widths) may only detect large-scale changes in snow cover (Hall et al. 2002; Nagler et al. 2008) and in landsurface greenness (Zeng and Jia 2013; Myers-Smith et al. 2020), but do not detect small-scale ecosystem processes driven by snow cover (Myers-Smith et al. 2020).

Snow cover is spatially and temporally heterogeneous and, in particular, snowmelt and snow accumulation patterns can vary across landscapes with varied topography (Marsh et al. 1997; Aalstad et al. 2020; Pedersen et al. 2021). Recently, drones have successfully been used 
Fig. 3. Snowmelt timing along natural snow gradients (caused by topography, wind, etc.) varies considerably at individual sites (multiple sites across western Norway in the SeedClim data) and between years (see methods for site selection, calculations etc.). The X-axis represents the day of the year (DOY) on which snowmelt occurs. Different dots represent plots within one studied gradient in a given year. Site-year combinations are ordered first by mean snowmelt date of sites (across years per site) and then by year. Different site-year combinations can be from the same study. Most studies include only small elevation differences (except Norway); hence, the snow differences are caused by micro-topography, wind drift, and other factors. Japan: $43.67^{\circ} \mathrm{N}, 142.91^{\circ} \mathrm{E}, 1800 \mathrm{~m}$ a.s.l. (Kudo 2016); Greenland: $69.27^{\circ} \mathrm{N}, 53.50^{\circ} \mathrm{E}, 90 \mathrm{~m}$ a.s.l.; Finland: $69.06^{\circ} \mathrm{N}, 20.81^{\circ} \mathrm{E}, 697-768 \mathrm{~m}$ a.s.1.; Norway: $60.54-61.09^{\circ} \mathrm{N} 5.96-8.70^{\circ} \mathrm{E}, 346-1213 \mathrm{~m}$ a.s.1.

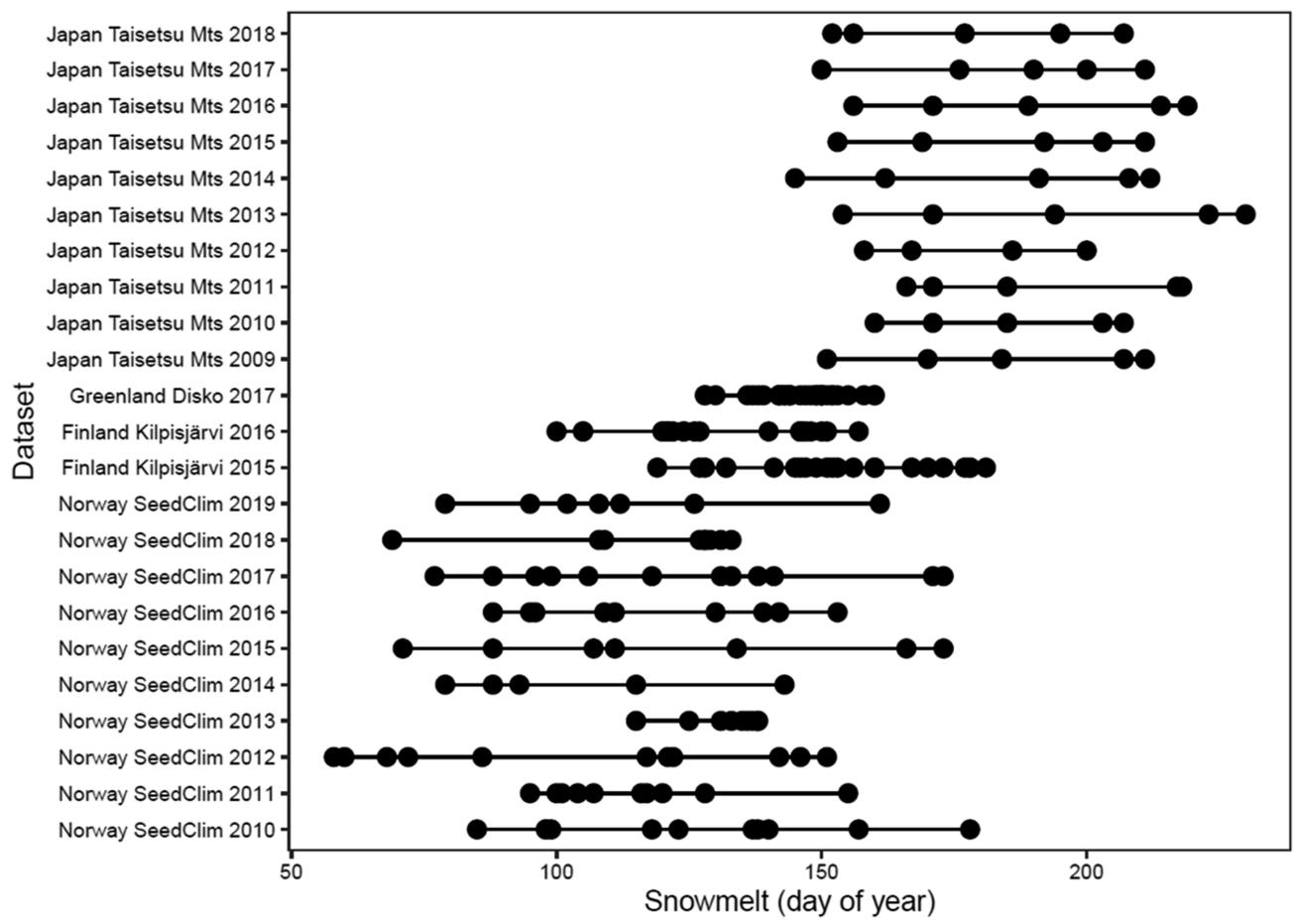

for recording and seasonal monitoring of ecosystem properties even in climatically challenging tundra environments (Fraser et al. 2016; Assmann et al. 2020; Siewert and Olofsson 2020). Drones and high-resolution satellite imagery can resolve small scale variability in snow extent, often measured as fractional snow-covered area (fSCA) (Liang et al. 2017; Aalstad et al. 2020), snow thickness (Grünberg et al. 2020; Harder et al. 2020), or snow depth (Pedersen et al. 2018; Pedersen et al. 2021). Snow cover can be coupled with hydrological analyses, for example by estimating the snow water equivalent (Liston and Sturm 2002; Dozier et al. 2016; Niedzielski et al. 2019), or to understand the impact of snowbeds on vegetation productivity (Borner et al. 2008; Siewert and Olofsson 2020).

Mapping snow extent can be easily achieved from optical sensors due to the high spectral contrast of snow. Similarly, snow algae can be measured as they influence the optical properties of snow (Davey et al. 2019; Gray et al. 2020). Estimating snow thickness using drones typically relies on the generation of a digital elevation model (DEM) using either structure from motion (SfM) or LiDAR approaches, followed by subtracting a snow-free reference DEM (Niedzielski et al. 2019; Harder et al. 2020; Walker et al. 2021). Drones can be particularly useful in spring, when snowmelt dynamics are fast but cloud cover can prevent satellite observations. Here, repeated drone flights provide temporally resolved 
estimates of snowmelt (Siewert and Olofsson 2020). Another approach is the use of near-remote sensing, for example with instruments (e.g., time-lapse camera networks) permanently mounted on poles $2 \mathrm{~m}$ above a given plot and able to take multiple measurements of the same plots (Anderson et al. 2016a; Parmentier et al. 2021) to follow the vegetation development from snowmelt throughout the growing season and relate this to environmental conditions experienced.

\section{Natural gradients}

An obvious approach to studying effects of snow is along natural gradients of snowmelt resulting, for example, from microtopography under the same climatic conditions or along large climate gradients (Borner et al. 2008; Rammig et al. 2010; Vandvik et al. 2020). However, these natural gradients, as with any observational approach, often co-vary with features such as aspect, slope, etc. (Dunne et al. 2004). Our snow timing data show by how much snowmelt date can vary within a single gradient and year (Fig. 3, see methods). The timespan between the earliest and the latest snowmelt date along a gradient can be up to two months. The earliest snowmelt recorded in our data was day 58 (equating to 27 February in the Northern Hemisphere - for dates from Southern Hemisphere studies we subtracted 182 from the day of year to give consistency in numbers) and the latest was day 230 (equating to 18 August). Mean site differences in snowmelt timing due to microtopographic gradients was 56 days. At sites with extremely late snowmelt, vegetation is dominated by snowbed specialists with low above-ground biomass (such as Salix herbacea L.) (Wheeler et al. 2016). By contrast, at sites with early snowmelt such as ridges or hummocks, specialists adapted to freezing temperatures and dry conditions dominate. At sites with an intermediate snowmelt timing, the most favourable conditions for plant growth can be found, with intermediate soil moisture levels, a moderate growing season length, and a moderate level of protection from freezing events (Walker et al. 1993).

Alongside geographical gradients, snowmelt date can vary over time. For example, a site that has been monitored daily since 1975 for snowpack and snowmelt at the RMBL (southwest Colorado, at 2,915 $\mathrm{m}$ a.s.1.) has an average snowmelt date of 20 May, ranging from 24 April to 19 June, paralleling the snowfall variation in the preceding winter (mean maximum depth of snowfall of $10.6 \mathrm{~m}$, ranging from $4.74 \mathrm{~m}$ to $16.41 \mathrm{~m}$ ). The wide range of microhabitats available in an environment can create an even greater range of snowmelt dates through a combination of spatial and interannual variability.

\section{Snow manipulation experiments}

In many studies, snow cover has been manipulated experimentally, either by removing snow and, hence, advancing snowmelt, or by adding snow and postponing snowmelt. A convenient way to add snow is by installing fences in areas with a dominant wind direction. A snowdrift forms on the lee side of the fence, and snow depth can additionally be reduced on the exposed side (Jones et al. 1998; Walker et al. 1999; Morgner et al. 2010; Mark et al. 2015; Ricketts et al. 2016; D'Imperio et al. 2018; Jespersen et al. 2018). If fences are sufficiently long, the area of increased snow may well be large enough to have a considerable effect on both aboveground and belowground parts of the vegetation (Welker et al. 2005a) and, thus, avoid the problems associated with other approaches as discussed below, with small treatment plots with proportionately large edge effects.

Manipulating snow manually by shoveling is more labour intensive and may alter snow properties, yet has the advantage that a higher number of well-defined plots in a given area can be treated. Also, removals and additions can be realized in close proximity under controlled conditions (Wipf et al. 2006; Anderson and Wadgymar 2019; Wadgymar et al. 2019; Frei and Henry 2021). Snowmelt can also be accelerated by positioning a dark cloth on the 
snow surface that increases the absorption of solar radiation (Steltzer et al. 2009; BlumeWerry et al. 2017). Experimental snowmelt change has also been achieved using infrared heaters (Harte and Shaw 1995; Harte et al. 1995; Harte et al. 2015; Winkler et al. 2016; Panetta et al. 2018; Harte 2019; Jabis et al. 2020a), heating cables in the ground (Rixen et al. 2012), the combination of both (Bokhorst et al. 2008; Bokhorst et al. 2011a), dust or black sand on snow (Blankinship et al. 2014) or reflective surfaces on snow (Blankinship et al. 2014).

By analyzing the snowmelt date based on the marked increase in temperature fluctuation after the extended period of the zero curtain we quantified delays and advances in the meltout date caused by the snow manipulation experiments (Fig. 2). On average, snow addition delayed snowmelt by 5.5 days $( \pm 8.2 \mathrm{SD})$, and snow removal advanced snowmelt by 7.9 days $( \pm 8.4 \mathrm{SD})$. The experiments varied considerably in their timing of snowmelt with respect to day of the year, from day 49 to day 188 (equating to 18 February and early July in the Northern Hemisphere). We do not have complete information of the amounts of snow that were added or removed in the experiments. But from those studies where snow depth information is available, we see that on average $80 \mathrm{~cm}$ of snow is added (ranging from approximately 40 to $150 \mathrm{~cm}$, see Supplementary Table $S 1^{2}$ ). This addition of snow corresponded to approximately 10 days delay in snowmelt. The amount of snow added did not correlate with days of delay in snowmelt (results not shown), which indicates that temperatures and radiation are just as important, if not more important, for snowmelt timing as the amounts of snow.

The experimental manipulations of snow cover only caused minor changes in snowmelt timing compared with the large natural differences in snowmelt that exist because of topography, wind drift, interannual variation, etc., and impacts on the studied ecosystems should, thus, always be interpreted with these numbers in mind. However, the change in snowmelt timing depended upon the natural timing of snowmelt, as snow treatments at sites with earlier natural snowmelt had larger experimental effects than those at sites with late natural snowmelt (Fig. 4).

One way to use the natural snow gradient experimentally is to carry out transplants across the snow gradient. In a transplant study with the dwarf willow Salix herbacea, the difference in snowmelt timing between snowbeds and ridges was about one month, and phenological responses of $S$. herbacea to the very different times of melt-out were highly plastic (Sedlacek et al. 2015).

The variability of responses to snow manipulation experiments is, in general, very high (Wipf and Rixen 2010). The timing in the season when a snow manipulation is carried out can to some degree explain seemingly contradictory plant responses in different studies. If, for instance, a snow addition is made in a system where the natural snowmelt is already very late (e.g., Jespersen et al. 2018), the experiment is likely to make the growing conditions more extreme, effectively by shortening the already short growing season. Plant growth and productivity are, hence, likely to be reduced. By contrast, if snow addition is carried out early in spring or summer, it is likely to make growing conditions more benign, for instance by providing protection from freezing events and cold temperatures (Klein et al. 2018; Vitasse et al. 2018), or by improving soil moisture conditions. The opposite can be expected for the advancement of snowmelt by snow removal. In a long-term snow removal study, all species of a plant community responded with decreased growth during the subsequent summer, with the exception of Loiseleuria procumbens (L.) Desv., a species characteristic of the most extreme end of the snow gradient, where early snowmelt and extreme temperature fluctuations are experienced (see above) (Wipf et al. 2009). 
Fig. 4. Effect size of snow treatments is more pronounced at plots with early snowmelt. The effect size is the number of days advancement or delay in snowmelt timing caused by both snow addition and removal and was calculated for removals as control - removal, and for additions as addition - control. See Fig. 2 for origin of data points. Effect size is larger at sites with earlier natural snowmelt $(p<0.01)$ and equally driven by addition and removal treatments (interaction treatment type $\times$ snowmelt day in control plot not shown).

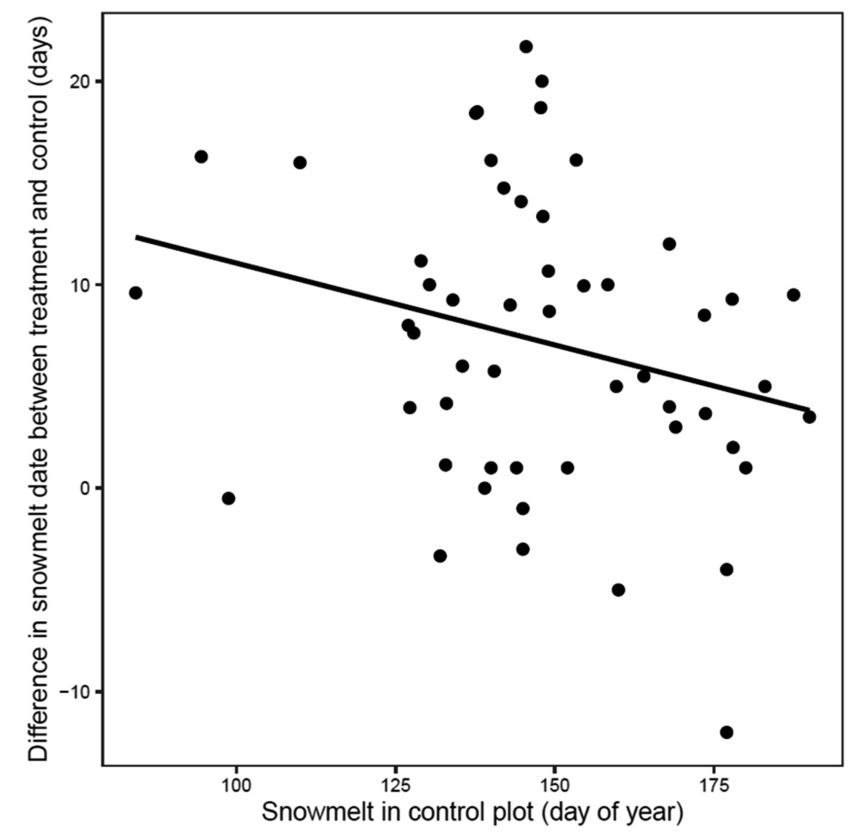

Open top chambers (OTCs) $\times$ snow manipulations

An increasing number of studies have combined snow manipulations with warming by OTCs (Dorrepaal et al. 2004; Weedon et al. 2012; Drescher 2014; Suzuki 2014; Weedon et al. 2014; Gillespie et al. 2016; Christiansen et al. 2017; D’Imperio et al. 2018; Darrouzet-Nardi et al. 2019; Mörsdorf et al. 2019; Frei and Henry 2021; Thompson et al. 2021). Both treatments can affect plant growth and biogeochemical processes, but can have different effects depending on mechanisms at work. Warming can, for instance, cause drying of soils, whereas snow addition by snow fences can increase soil moisture (Schollert et al. 2017). The combined effects of warming and increased snow depth can change the plant community composition and increase primary productivity (Leffler et al. 2016). Warmer spring temperatures and deeper snow can also have opposing effects, e.g. on litter decomposition (Farrer et al. 2015; Blok et al. 2016).

An unintended consequence of the widely-used OTC methodology of experimentally manipulating air temperature in polar field experiments studying potential consequences of warming can be the accumulation of snow within the chambers when left in place over winter. This can lead to artifacts in the data obtained both in terms of winter temperature regime and extended snow cover within the experiment (Dorrepaal et al. 2009; Bokhorst et al. 2011b; Bokhorst et al. 2013a). For instance, increased snow depth in OTCs led to near complete disappearance of a previously dominant lichen species (Bokhorst et al. 2016a). We would, therefore, encourage authors to state whether their OTCs are removed or left on the plots during winter when reporting their results. Nevertheless, leaving OTCs in place in winter remains advantageous as it enables a combination of snow increase in winter and 
summer warming (for a comparison of effects of winter and summer warming on tundra see Pold et al. 2021).

\section{Future research priorities}

New technology to sense snow and snowmelt dynamics

New technology including drones (Assmann et al. 2020; Siewert and Olofsson 2020), LiDAR and radar observations (Harder et al. 2020), and higher-resolution optical satellite imagery will allow us to capture snow and snowmelt dynamics missed by historical data collection. Integrating these new technologies into future in situ ecological data collection will allow for a better understanding of the fine spatial and temporal scale dynamics of snowmelt and resulting ecological processes such as plant phenology. There is a continued need, however, for improving the validation between remotely-sensed and ground-based observations of phenology (see, e.g. Karlsen et al. 2021 for an approach). Further development of in situ low-cost snow monitoring techniques (e.g., Lewkowicz 2008; Siren et al. 2018; Tutton and Way 2021) and expanded winter field data collection should also be prioritized to provide better validation of remotely-sensed snow products (Walker et al. 2021).

\section{Changing phenology and trophic interactions under altered snow regimes}

New technologies will allow us to answer questions about how changing snow regimes are altering the landscape heterogeneity of tundra plant productivity both above- and below-ground. Earlier snowmelt in the tundra can advance plant phenological stages (e.g., Assmann et al. 2020), and altered snow regimes can influence trophic interactions by changing the availablity of plant resources across the landscape (e.g., Berteaux et al. 2017; Gillespie and Cooper 2021). A research priority is also to improve quantitative (and not only qualitative) impacts of climate and vegetation changes on snow properties.

Influence of changing snowmelt dynamics and winter extreme events on tundra biodiversity

Changing snow regimes and more frequent winter extreme events could have cumulative impacts on tundra biodiversity. Longer summer growing seasons or frost tolerance could alter community composition (Bokhorst et al. 2018). Experiments that test the sensitivity of plants, microbes, and soils to snow regimes and winter conditions beyond those currently experienced in tundra ecosystems will shed light on the composition of tundra that could be expected with future climate change.

\section{Conclusions}

Snow and changes in snow cover are key drivers of ecological processes in cold ecosystems. Snow and snowmelt dynamics alter plant growing season length, phenology, growth, community composition, soil moisture and biogeochemistry, carbon sequestration, and trophic interactions. We find that the difference in snow-free season length can be up to two months in snow manipulation studies and along natural local and regional snowmelt gradients. However, most snow manipulation experiments change the snowmelt timing by a much shorter amount, often by only a few days. In addition, the time of the year when snow studies have been carried out varies markedly. In this review, we have taken the first steps in providing an improved baseline for future studies of the influence of snow on terrestrial ecosystems. Differences between snow study approaches need to be accounted for when drawing ecological conclusions and projecting snow dynamics and their impact on ecosystems in future climates. Along with these temporal considerations, questions regarding the spatial scale of effects must be addressed using study designs that incorporate multiple spatial extents and resolutions of snow cover and depth measurements, to better link plot-level observations to landscape-scale dynamics, and we, thus, recommend further 
comparisons between natural gradient and experimental studies (see e.g., Gehrmann et al. 2022; Moriana-Armendariz et al. 2022). Our analysis of temperature data across many studies and years can and should be expanded, to quantify winter temperature fluctuations, the frequency and intensity of freezing events, freeze-thaw cycles, ROS events and build-up of the snow cover in autumn. Gathering global data focusing on the impacts of snow on tundra ecosystems has the potential to considerably improve our understanding of cold ecosystems in times of climate change.

\section{Funding statement}

This work and the extensive data collection was supported by numerous institutions and funding agencies namely: EU H2020 CHARTER project; NSF award numbers 1836873 1504141, 1433063, 0119279, 0856728, 0632184, 9617643, 9321730, DEB-1912006, DEB-1354104, OPP-1504538, DEB-1354104; the Czech Science Foundation 17-20839S; the Norwegian Research Council (“SnoEco" project, number 230970, and grants 171542, 225006, NORKLIMA 184912 and KLIMAFORSK 244525), the FRAM Centre Terrestrial Framework (project: “Summer's End"); the Norwegian Centre for International Cooperation in Education (SIU) High North Programme (“JANATEX” project, number HNP2013/10092); the UiT-The Arctic University of Norway; the BECC - Biodiversity and Ecosystem services in a Changing Climate; the European Union's Horizon 2020 research and innovation program under the Marie Skłodowska-Curie Grant Agreement No. 657627; the Swedish Research Council FORMAS - future research leaders No. 2016-01187; the NSF-supported Niwot Ridge LTER program (NSF DEB - 1637686); Funding by the Research Foundation Flanders (project numbers OZ7828, OZ7916, OZ8323 and OZ7792); Natural Sciences and Engineering Research Council of Canada, ArcticNet, Canadian International Year Program, Northern Science Training Program (Polar Knowledge Canada), Polar Continental Shelf Program, and logistical support from the Royal Canadian Mounted Police; the Nunavut Department of Environment and the Qikiqtani Inuit Association; the Danish National Research Foundation (CENPERM DNRF100); the Doctoral Programme in Plant Science (University of Helsinki); the Finnish Society of Forest Sciences; Nordenskiöld-samfundet; Societas pro Fauna et Flora Fennica and Oskar Öflunds Stiftelse to FG; the Academy of Finland, University of Oulu; the National Research Foundation of Korea [NRF-2021M1A5A1075508, PN22012]; the Center för Miljöforskning and Kempe Foundation; NERC core funding to BAS; the Swiss National Science Foundation; the Netherlands Polar Programme; Qatar Petroleum; Kempestiftelserna Ref.No JCK-1822; the Australian Research Council Discovery Early Career Research Award DE140101611.

\section{Contributors' statement}

CR, TTH, PM, EJC, ED, CTC and SW conceived the idea for the paper. The following people contributed substantially to the acquisition of data, and the analysis and interpretation of data: CR, TTH, PM, RA, JMA, JTA, PAA, ICB, JWB, MPB, DB, GBW, JB, SB, MC, CTC, PC, EJC, JHCC, SJC, ED, BE, SCE, CE, TGWF, ERF, SRG, FG, CG, PG, JH, GHRH, DI, REI, GJ, ISJ, JYJ, DK, GK, JL, HL, JJL, SL, MM, JM, IMS, JO, RP, AP, GKP, HMRM, PS, MBS, RS, MJS, KS, PS, KLT, MV, VV, SV, JMW, RW, JMW, SW and SZ. CR led the writing of the manuscript with substantial contributions from TTH, PM, ICB, MPB, CTC, EJC, REI, JO, PS, MBS, JMW, RA, JMA, JTA, PAA, JWB, DB, GBW, JB, SB, MC, PC, JHCC, SJC, ED, BE, SCE, CE, TGWF, ERF, SRG, FG, CG, PG, JH, GHRH, DI, GJ, ISJ, JYJ, DK, GK, JL, HL, JJL, SL, MM, JM, IMS, RP, AP, GKP, HMRM, PS, RS, MJS, KS, KLT, MV, VV, SV, JMW, RW, SW and SZ. All co-authors provided editorial writing to one or more manuscript drafts, all co-authors approved the final version of the manuscript and agree to be accountable for the work. 


\section{Data availability statement}

The data used for the paper can be requested from the corresponding author.

\section{Acknowledgements}

We are grateful to Regin Rønn, Olivia Lyster, Alistair McConnell, Laurenz Teuber, and Maria-Theresa Jessen.

\section{References}

Aalstad, K., Westermann, S., and Bertino, L. 2020. Evaluating satellite retrieved fractional snow-covered area at a high-Arctic site using terrestrial photography. Remote Sens. Environ. 239: 111618. doi:10.1016/j.rse.2019.111618.

Abramoff, R.Z., and Finzi, A.C. 2015. Are above- and below-ground phenology in sync? New Phytol. 205(3): 1054-1061. doi:10.1111/nph.13111.

Ackerman, D., Griffin, D., Hobbie, S.E., and Finlay, J.C. 2017. Arctic shrub growth trajectories differ across soil moisture levels. Global Change Biol. 23(10): 4294-4302. doi:10.1111/gcb.13677.

Aerts, R., Callaghan, T.V., Dorrepaal, E., van Logtestijn, R.S.P., and Cornelissen, J.H.C. 2012. Seasonal climate manipulations have only minor effects on litter decomposition rates and $\mathrm{N}$ dynamics but strong effects on litter $\mathrm{P}$ dynamics of sub-arctic bog species. Oecologia 170(3): 809-819. doi:10.1007/s00442-012-2330-z.

Amagai, Y., Kudo, G., and Sato, K. 2018. Changes in alpine plant communities under climate change: dynamics of snow-meadow vegetation in northern Japan over the last 40 years. Appl. Veg. Sci. 21(4): 561-571. doi:10.1111/ avsc.12387.

Anderson, H.B., Godfrey, T.G., Woodin, S.J., and van der Wal, R. 2012. Finding food in a highly seasonal landscape: where and how pink footed geese Anser brachyrhynchus forage during the Arctic spring. J. Avian Biol. 43(5): 415-422. doi:10.1111/j.1600-048X.2012.05699.x.

Anderson, H.B., Nilsen, L., Tømmervik, H., Karlsen, S.R., Nagai, S., and Cooper, E.J. 2016a. Using ordinary digital cameras in place of near-infrared sensors to derive vegetation indices for phenology studies of High Arctic vegetation. Remote Sens. 8(10): 847. doi:10.3390/rs8100847.

Anderson, H.B., Speed, J.D.M., Madsen, J., Pedersen, A.O., Tombre, I.M., and van der Wal, R. 2016b. Late snow melt moderates herbivore disturbance of the Arctic tundra. Ecoscience 23(1-2): 29-39. doi:10.1080/ 11956860.2016.1212684.

Anderson, J.T., and Wadgymar, S.M. 2019. Climate change disrupts local adaptation and favours upslope migration. Ecol. Lett. 23(1): 181-192 doi:10.1111/ele.13427.

Assmann, J.J., Myers-Smith, I.H., Kerby, J.T., Cunliffe, A.M., and Daskalova, G.N. 2020. Drone data reveal fine-scale variation of tundra greenness and phenology not captured by satellite and ground-based monitoring. Environ. Res. Lett. 15: 125002. doi:10.1088/1748-9326/abbf7d.

Assmann, J.J., Myers-Smith, I.H., Phillimore, A.B., Bjorkman, A.D., Ennos, R.E., Prevey, J.S., et al. 2019. Local snow melt and temperature-but not regional sea ice-explain variation in spring phenology in coastal Arctic tundra. Global Change Biol. 25(7): 2258-2274. doi:10.1111/gcb.14639.

Baker, D.G., Skaggs, R.H., and Ruschy, D.L. 1991. Snow depth required to mask the underlying surface. J. Appl. Meteorol. 30(3): 387-392. doi:10.1175/1520-0450(1991)030<0387:SDRTMT>2.0.CO;2.

Bale, J.S., and Hayward, S.A.L. 2010. Insect overwintering in a changing climate. J. Exp. Biol. 213(6): 980-994. doi:10.1242/jeb.037911.

Bales, R.C., Davis, R.E., and Stanley, D.A. 1989. Ion elution through shallow homogeneous snow. Water Resour. Res. 25(8): 1869-1877. doi:10.1029/WR025i008p01869.

Barbeito, I., Bruecker, R.L., Rixen, C., and Bebi, P. 2013. Snow Fungi-induced mortality of Pinus cembra at the Alpine Treeline: evidence from plantations. Arct. Antarct. Alp. Res. 45(4): 455-470. doi:10.1657/1938-4246-45.4.455.

Barbeito, I., Dawes, M., Rixen, C., Senn, J., and Bebi, P. 2012. Factors driving survival and growth at treeline: a 30-year experiment of 92000 conifers. Ecology 93(2): 389-401. doi:10.1890/11-0384.1.

Barrere, M., Domine, F., Belke-Brea, M., and Sarrazin, D. 2018. Snowmelt events in autumn can reduce or cancel the soil warming effect of snow-vegetation interactions in the Arctic. J. Clim. 31(23): 9507-9518. doi:10.1175/JCLI-D-180135.1.

Belke-Brea, M., Domine, F., Barrere, M., Picard, G., and Arnaud, L. 2020. Impact of shrubs on winter surface albedo and snow specific surface area at a low arctic site: in situ measurements and simulations. J. Clim. 33(2): 597-609. doi:10.1175/JCLI-D-19-0318.1.

Belshe, E.F., Schuur, E.A.G., and Bolker, B.M. 2013. Tundra ecosystems observed to be $\mathrm{CO}_{2}$ sources due to differential amplification of the carbon cycle. Ecol. Lett. 16(10): 1307-1315. doi:10.1111/ele.12164.

Beniston, M., and Stoffel, M. 2016. Rain-on-snow events, floods and climate change in the Alps: events may increase with warming up to $4{ }^{\circ} \mathrm{C}$ and decrease thereafter. Sci. Total Environ. 571: 228-236. doi:10.1016/ j.scitotenv.2016.07.146. PMID:27476005.

Berg, T.B., Schmidt, N.M., Hoye, T.T., Aastrup, P.J., Hendrichsen, D.K., Forchhammer, M.C., and Klein, D.R. 2008. High-arctic plant-herbivore interactions under climate influence. In Advances in ecological research, vol 40: high-arctic ecosystem dynamics in a changing climate. Vol. 40. Edited by H. Meltofte, T.R. Christensen, B. Elberling, M.C. Forchhammer, and M. Rasch. Advances in Ecological Research. pp. 275-298. 
Berteaux, D., Gauthier, G., Domine, F., Ims, R.A., Lamoureux, S.F., Levesque, E., and Yoccoz, N. 2017. Effects of changing permafrost and snow conditions on tundra wildlife: critical places and times. Arct. Sci. 3(2): 65-90. doi: $10.1139 /$ as-2016-0023.

Billings, W.D. 1969. Vegetational pattern near alpine timberline as affected by fire-snowdrift interactions. Vegetatio 19: 192-207. doi:10.1007/BF00259010.

Bintanja, R. 2018. The impact of Arctic warming on increased rainfall. Sci. Rep. 8: 16001. doi:10.1038/s41598-01834450-3.

Bjerke, J.W., Bokhorst, S., Zielke, M., Callaghan, T.V., Bowles, F.W., and Phoenix, G.K. 2011. Contrasting sensitivity to extreme winter warming events of dominant sub-Arctic heathland bryophyte and lichen species. J. Ecol. 99(6): 1481-1488. doi:10.1111/j.1365-2745.2011.01859.x.

Bjerke, J.W., Treharne, R., Vikhamar-Schuler, D., Karlsen, S.R., Ravolainen, V., Bokhorst, S., et al. 2017. Understanding the drivers of extensive plant damage in boreal and Arctic ecosystems: insights from field surveys in the aftermath of damage. Sci. Total Environ. 599: 1965-1976. doi:10.1016/j.scitotenv.2017.05.050. PMID:28558420.

Björk, R.G., and Molau, U. 2007. Ecology of alpine snowbeds and the impact of global change. Arct. Antarct. Alp. Res. 39(1): 34-43. doi:10.1657/1523-0430(2007)39[34:Eoasat]2.0.Co;2.

Bjorkman, A.D., Elmendorf, S.C., Beamish, A.L., Vellend, M., and Henry, G.H.R. 2015. Contrasting effects of warming and increased snowfall on Arctic tundra plant phenology over the past two decades. Global Change Biol. 21(12): 4651-4661. doi:10.1111/gcb.13051.

Björkman, M.P., Vega, C.P., Kuhnel, R., Spataro, F., Ianniello, A., Esposito, G., et al. 2014. Nitrate postdeposition processes in Svalbard surface snow. J. Geophys. Res. Atmo. 119(22): 12953-12976. doi:10.1002/2013jd021234.

Blanc-Betes, E., Welker, J.M., Sturchio, N.C., Chanton, J.P., and Gonzalez-Meler, M.A. 2016. Winter precipitation and snow accumulation drive the methane sink or source strength of Arctic tussock tundra. Global Change Biol. 22(8): 2818-2833. doi:10.1111/gcb.13242.

Blankinship, J.C., Meadows, M.W., Lucas, R.G., and Hart, S.C. 2014. Snowmelt timing alters shallow but not deep soil moisture in the Sierra Nevada. Water Resour. Res. 50(2): 1448-1456. doi: 10.1002/2013WR014541.

Blok, D., Elberling, B., and Michelsen, A. 2016. Initial stages of Tundra Shrub litter decomposition may be accelerated by deeper winter snow but slowed down by spring warming. Ecosystems 19(1): 155-169. doi: 10.1007/s10021015-9924-3.

Blume-Werry, G., Jansson, R., and Milbau, A. 2017. Root phenology unresponsive to earlier snowmelt despite advanced above-ground phenology in two subarctic plant communities. Funct. Ecol. 31(7): 1493-1502. doi:10.1111/ 1365-2435.12853.

Blume-Werry, G., Wilson, S.D., Kreyling, J., and Milbau, A. 2016. The hidden season: growing season is 50\% longer below than above ground along an arctic elevation gradient. New Phytol. 209(3): 978-986. doi:10.1111/nph.13655.

Bokhorst, S., Bjerke, J.W., Bowles, F.W., Melillo, J., Callaghan, T.V., and Phoenix, G.K. 2008. Impacts of extreme winter warming in the sub-Arctic: growing season responses of dwarf shrub heathland. Global Change Biol. 14(11): 2603-2612. doi:10.1111/j.1365-2486.2008.01689.x.

Bokhorst, S., Bjerke, J.W., Davey, M.P., Taulavuori, K., Taulavuori, E., Laine, K., et al. 2010a. Impacts of extreme winter warming events on plant physiology in a sub-Arctic heath community. Physiol. Plant. 140(2): 128-140. doi:10.1111/j.1399-3054.2010.01386.x.

Bokhorst, S., Bjerke, J.W., Melillo, J., Callaghan, T.V., and Phoenix, G.K. 2010b. Impacts of extreme winter warming events on litter decomposition in a sub-Arctic heathland. Soil Biol. Biochem. 42(4): 611-617. doi:10.1016/ j.soilbio.2009.12.011.

Bokhorst, S., Bjerke, J.W., Street, L.E., Callaghan, T.V., and Phoenix, G.K. 2011a. Impacts of multiple extreme winter warming events on sub-Arctic heathland: phenology, reproduction, growth, and $\mathrm{CO}_{2}$ flux responses. Global Change Biol. 17(9): 2817-2830. doi:10.1111/j.1365-2486.2011.02424.x.

Bokhorst, S.F., Bjerke, J.W., Tømmervik, H., Callaghan, T.V., and Phoenix, G.K. 2009. Winter warming events damage sub-Arctic vegetation: consistent evidence from an experimental manipulation and a natural event. J. Ecol. 97(6): 1408-1415. doi:10.1111/j.1365-2745.2009.01554.x.

Bokhorst, S., Convey, P., Huiskes, A., and Aerts, R. 2016a. Usnea antarctica, an important Antarctic lichen, is vulnerable to aspects of regional environmental change. Polar Biol. 39(3): 511-521. doi: 10.1007/s00300-015-1803-z.

Bokhorst, S., Huiskes, A., Aerts, R., Convey, P., Cooper, E.J., Dalen, L., et al. 2013a. Variable temperature effects of Open Top Chambers at polar and alpine sites explained by irradiance and snow depth. Global Change Biol. 19(1): 64-74. doi:10.1111/gcb.12028.

Bokhorst, S., Huiskes, A., Convey, P., Sinclair, B.J., Lebouvier, M., Van de Vijver, B., and Wall, D.H. $2011 b$. Microclimate impacts of passive warming methods in Antarctica: implications for climate change studies. Polar Biol. 34(10): 1421-1435. doi:10.1007/s00300-011-0997-y.

Bokhorst, S., Jaakola, L., Karppinen, K., Edvinsen, G.K., Maehre, H.K., and Bjerke, J.W. 2018. Contrasting survival and physiological responses of sub-Arctic plant types to extreme winter warming and nitrogen. Planta 247(3): 635-648. doi:10.1007/s00425-017-2813-6.

Bokhorst, S., Metcalfe, D.B., and Wardle, D.A. 2013b. Reduction in snow depth negatively affects decomposers but impact on decomposition rates is substrate dependent. Soil Biol. Biochem. 62: 157-164. doi:10.1016/ j.soilbio.2013.03.016.

Bokhorst, S., Pedersen, S.H., Brucker, L., Anisimov, O., Bjerke, J.W., Brown, R.D., et al. 2016b. Changing Arctic snow cover: a review of recent developments and assessment of future needs for observations, modelling, and impacts. Ambio 45(5): 516-537. doi:10.1007/s13280-016-0770-0. 
Bormann, K.J., Brown, R.D., Derksen, C., and Painter, T.H. 2018. Estimating snow-cover trends from space. Nat. Clim. Change 8(11): 923-927. doi: 10.1038/s41558-018-0318-3.

Borner, A.P., Kielland, K., and Walker, M.D. 2008. Effects of simulated climate change on plant phenology and nitrogen mineralization in Alaskan arctic Tundra. Arct. Antarct. Alp. Res. 40(1): 27-38. doi: 10.1657/1523-0430(06099)[BORNER]2.0.CO;2.

Brooks, P.D., Grogan, P., Templer, P.H., Groffman, P., Öquist, M.G., and Schimel, J. 2011. Carbon and nitrogen cycling in snow-covered environments. Geogr. Compass.: 682-699. doi: 10.1111/j.1749-8198.2011.00420.x.

Brooks, P.D., McKnight, D., and Elder, K. 2005. Carbon limitation of soil respiration under winter snowpacks: potential feedbacks between growing season and winter carbon fluxes. Global Change Biol. 11(2): 231-238. doi: 10.1111/ j.1365-2486.2004.00877.x.

Buckeridge, K.M., Banerjee, S., Siciliano, S.D., and Grogan, P. 2013. The seasonal pattern of soil microbial community structure in mesic low arctic tundra. Soil Biol. Biochem. 65: 338-347. doi: 10.1016/j.soilbio.2013.06.012.

Buckeridge, K.M., and Grogan, P. 2010. Deepened snow increases late thaw biogeochemical pulses in mesic low arctic tundra. Biogeochemistry 101(1-3): 105-121. doi: 10.1007/s10533-010-9426-5.

Callaghan, T.V., and Johannson, M. 2021. Snow, ice and the biosphere. In Snow and ice-related hazards, risks and disasters. Vol. 2. Edited by W. Haeberli and C. Whiteman, pp. 137-164.

Callaghan, T.V., Johansson, M., Brown, R.D., Groisman, P.Y., Labba, N., Radionov, V., et al. 2011. The changing face of Arctic snow cover: a synthesis of observed and projected changes. Ambio 40: 17-31. doi: 10.1007/s13280-011-0212-y.

Campbell, J.L., Mitchell, M.J., Groffman, P.M., Christenson, L.M., and Hardy, J.P. 2005. Winter in northeastern North America: a critical period for ecological processes. Front. Ecol. 3(6): 314-322. doi: 10.1890/1540-9295(2005)003[0314: WINNAA]2.0.CO;2.

Carbognani, M., Bernareggi, G., Perucco, F., Tomaselli, M., and Petraglia, A. 2016. Micro-climatic controls and warming effects on flowering time in alpine snowbeds. Oecologia 182(2): 573-585. doi: 10.1007/s00442-016-3669-3.

Carbognani, M., Petraglia, A., and Tomaselli, M. 2014. Warming effects and plant trait control on the early-decomposition in alpine snowbeds. Plant Soil 376(1-2): 277-290. doi: 10.1007/s11104-013-1982-8.

Christiansen, C.T., Haugwitz, M.S., Prieme, A., Nielsen, C.S., Elberling, B., Michelsen, A., Grogan, P., and Blok, D. 2017. Enhanced summer warming reduces fungal decomposer diversity and litter mass loss more strongly in dry than in wet tundra. Global Change Biol. 23(1): 406-420. doi: 10.1111/gcb.13362.

Christiansen, C.T., Lafrenière, M.J., Henry, G.H.R., and Grogan, P. 2018a. Long-term deepened snow promotes tundra evergreen shrub growth and summertime ecosystem net $\mathrm{CO}_{2}$ gain but reduces soil carbon and nutrient pools. Global Change Biol. 24(8): 3508-3525. doi: 10.1111/gcb.14084.

Christiansen, C.T., Mack, M.C., DeMarco, J., and Grogan, P. 2018b. Decomposition of senesced leaf litter is faster in tall compared to low birch shrub tundra. Ecosystems 21(8): 1564-1579. doi: 10.1007/s10021-018-0240-6.

Cockell, C.S., and Cordoba-Jabonero, C. 2004. Coupling of climate change and biotic UV exposure through changing snow-ice covers in terrestrial habitats. Photochem. Photobiol. 79(1): 26-31. doi: 10.1111/j.1751-1097.2004.tb09853.x.

Colbeck, S.C. 1983. Theory of metamorphism of dry snow. J. Geophys. Res. Oceans. 88(NC9): 5475-5482. doi: 10.1029/ JC088iC09p05475.

Collins, C.G., Elmendorf, S.C., Hollister, R.D., Henry, G.H.R., Clark, K., Bjorkman, A.D., et al. 2021. Experimental warming differentially affects vegetative and reproductive phenology of tundra plants. Nat. Commun. 12(1). doi: 10.1038/s41467-021-23841-2.

Convey, P., Abbandonato, H., Bergan, F., Beumer, L.T., Biersma, E.M., Brathen, V.S., et al. 2015. Survival of rapidly fluctuating natural low winter temperatures by High Arctic soil invertebrates. J. Therm. Biol. 54: 111-117. doi: 10.1016/j.jtherbio.2014.07.009. PMID: 26615733.

Convey, P., Coulson, S.J., Worland, M.R., and Sjoblom, A. 2018. The importance of understanding annual and shorter-term temperature patterns and variation in the surface levels of polar soils for terrestrial biota. Polar Biol. 41(8): 1587-1605. doi: 10.1007/s00300-018-2299-0.

Cooper, E.J. 2014. Warmer shorter winters disrupt Arctic terrestrial ecosystems. In Annual review of ecology, evolution, and systematics, vol 45. Vol. 45. Edited by D.J. Futuyma. Annual Review of Ecology Evolution and Systematics. pp. 271-295.

Cooper, E.J., Dullinger, S., and Semenchuk, P. 2011. Late snowmelt delays plant development and results in lower reproductive success in the High Arctic. Plant Sci. 180(1): 157-167. doi: 10.1016/j.plantsci.2010.09.005.

Cooper, E.J., Little, C.J., Pilsbacher, A.K., and Mörsdorf, M.A. 2019. Disappearing green: Shrubs decline and bryophytes increase with nine years of increased snow accumulation in the High Arctic. J. Veg. Sci. 30(5): 857-867. doi: 10.1111/jvs.12793.

Cornelissen, J.H.C., van Bodegom, P.M., Aerts, R., Callaghan, T.V., van Logtestijn, R.S.P., Alatalo, J., et al. 2007. Global negative vegetation feedback to climate warming responses of leaf litter decomposition rates in cold biomes. Ecol. Lett. 10(7): 619-627. doi: 10.1111/j.1461-0248.2007.01051.x.

Coulson, S.J., Convey, P., Aakra, K., Aarvik, L., Avila-Jimenez, M.L., Babenko, A., et al. 2014. The terrestrial and freshwater invertebrate biodiversity of the archipelagoes of the Barents Sea, Svalbard, Franz Josef Land and Novaya Zemlya. Soil Biol. Biochem. 68: 440-470. doi: 10.1016/j.soilbio.2013.10.006.

Coulson, S.J., Leinaas, H.P., Ims, R.A., and Sovik, G. 2000. Experimental manipulation of the winter surface ice layer: the effects on a High Arctic soil microarthropod community. Ecography 23(3): 299-306. doi: 10.1111/j.16000587.2000.tb00285.x.

Crowther, T.W., Todd-Brown, K.E.O., Rowe, C.W., Wieder, W.R., Carey, J.C., Machmuller, M.B., et al. 2016. Quantifying global soil carbon losses in response to warming. Nature 540(7631): 104. doi: 10.1038/nature20150. 
Crowther, T.W., van Gestell, N., Shi, Z., van Groenigen, K.J., Osenberg, C.W., Andresen, L.C., et al. 2018. Predicting soil carbon loss with warming. Nature 554(7693): E4-E6. doi: 10.1038/nature20150.

Czimczik, C.I., and Welker, J.M. 2010. Radiocarbon content of $\mathrm{CO}_{2}$ respired from high Arctic Tundra in northwest Greenland. Arct. Antarct. Alp. Res. 42(3): 342-350. doi: 10.1657/1938-4246-42.3.342.

D’Imperio, L., Arndal, M.F., Nielsen, C.S., Elberling, B., and Schmidt, I.K. 2018. Fast responses of root dynamics to increased snow deposition and summer air temperature in an Arctic Wetland. Front. Plant Sci. 9. doi: 10.3389/ fpls.2018.01258.

Darrouzet-Nardi, A., Steltzer, H., Sullivan, P.F., Segal, A., Koltz, A.M., Livensperger, C., Schimel, J.P., and Weintraub, M.N. 2019. Limited effects of early snowmelt on plants, decomposers, and soil nutrients in Arctic tundra soils. Ecol. Evol. 9(4): 1820-1844. doi: 10.1002/ece3.4870.

Davesne, G., Fortier, D., Domine, F., and Gray, J.T. 2017. Wind-driven snow conditions control the occurrence of contemporary marginal mountain permafrost in the Chic-Choc Mountains, south-eastern Canada: a case study from Mont Jacques-Cartier. Cryosphere 11(3): 1351-1370. doi: 10.5194/tc-11-1351-2017.

Davey, M.P., Norman, L., Sterk, P., Huete-Ortega, M., Bunbury, F., Loh, B.K.W., et al. 2019. Snow algae communities in Antarctica: metabolic and taxonomic composition. New Phytol. 222(3): 1242-1255. doi: 10.1111/nph.15701.

Davis, E., Trant, A., Hermanutz, L., Way, R.G., Lewkowicz, A.G., Siegwart Collier, L., Cuerrier, A., and Whitaker, D. 2020. Plant-environment interactions in the Low Arctic Torngat Mountains of Labrador. Ecosystems 24(5): 1038-1058. doi: 10.1007/s10021-020-00577-6.

Dawes, M.A., Hagedorn, F., Zumbrunn, T., Handa, I.T., Hattenschwiler, S., Wipf, S., and Rixen, C. 2011. Growth and community responses of alpine dwarf shrubs to in situ $\mathrm{CO}_{2}$ enrichment and soil warming. New Phytol. 191(3): 806-818. doi: 10.1111/j.1469-8137.2011.03722.x.

De Boeck, H.J., Vicca, S., Roy, J., Nijs, I., Milcu, A., Kreyling, J., et al. 2015. Global change experiments: challenges and opportunities. Bioscience 65(9): 922-931. doi: 10.1093/biosci/biv099.

Dedieu, J.P., Carlson, B.Z., Bigot, S., Sirguey, P., Vionnet, V., and Choler, P. 2016. On the importance of highresolution time series of optical imagery for quantifying the effects of snow cover duration on Alpine plant habitat. Remote Sens. 8(6): 481. doi: 10.3390/rs8060481.

DeMarco, J., Mack, M.C., and Bret-Harte, M.S. 2014. Effects of arctic shrub expansion on biophysical vs. biogeochemical drivers of litter decomposition. Ecology 95(7): 1861-1875. doi: 10.1890/13-2221.1.

Dollery, R., Hodkinson, I.D., and Jónsdóttir, I.S. 2006. Impact of warming and timing of snow melt on soil microarthropod assemblages associated with Dryas-dominated plant communities on Svalbard. Ecography 29(1): 111-119. doi: 10.1111/j.2006.0906-7590.04366.x.

Domine, F., Barrere, M., and Morin, S. 2016. The growth of shrubs on high Arctic tundra at Bylot Island: impact on snow physical properties and permafrost thermal regime. Biogeosciences 13(23): 6471-6486. doi: 10.5194/bg-136471-2016.

Domine, F., Gauthier, G., Vionnet, V., Fauteux, D., Dumont, M., and Barrere, M. 2018. Snow physical properties may be a significant determinant of lemming population dynamics in the high Arctic. Arct. Sci. 4(4): 813-826. doi: 10.1139/as-2018-0008.

Dorrepaal, E., Aerts, R., Cornelissen, J.H.C., Callaghan, T.V., and van Logtestijn, R.S.P. 2004. Summer warming and increased winter snow cover affect Sphagnum fuscum growth, structure and production in a sub-Arctic bog. Global Change Biol. 10(1): 93-104. doi: 10.1111/j.1365-2486.2003.00718.x.

Dorrepaal, E., Toet, S., van Logtestijn, R.S.P., Swart, E., van de Weg, M.J., Callaghan, T.V., and Aerts, R. 2009. Carbon respiration from subsurface peat accelerated by climate warming in the subarctic. Nature 460(7255): 616-619. doi: 10.1038/nature08216.

Dozier, J., Bair, E.H., and Davis, R.E. 2016. Estimating the spatial distribution of snow water equivalent in the world's mountains. Wiley Interdiscip. Rev. Water 3(3): 461-474. doi: 10.1002/wat2.1140.

Drescher, M. 2014. Snow cover manipulations and passive warming affect post-winter seed germination: a case study of three cold-temperate tree species. Clim. Res. 60(3): 175-186. doi: 10.3354/cr01237.

Duchesne, D., Gauthier, G., and Berteaux, D. 2011. Habitat selection, reproduction and predation of wintering lemmings in the Arctic. Oecologia 167(4): 967-980. doi: 10.1007/s00442-011-2045-6.

Dunne, J.A., Saleska, S.R., Fischer, M.L., and Harte, J. 2004. Integrating experimental and gradient methods in ecological climate change research. Ecology 85(4): 904-916. doi: 10.1890/03-8003.

Elmendorf, S.C., Henry, G.H.R., Hollister, R.D., Björk, R.G., Boulanger-Lapointe, N., Cooper, E.J., et al. 2012. Plot-scale evidence of tundra vegetation change and links to recent summer warming. Nat. Clim. Change 2(6): 453-457. doi: 10.1038/nclimate1465.

Elmendorf, S.C., Henry, G.H.R., Hollister, R.D., Fosaa, A.M., Gould, W.A., Hermanutz, L., et al. 2015. Experiment, monitoring, and gradient methods used to infer climate change effects on plant communities yield consistent patterns. Proc. Natl. Acad. Sci. USA. 112(2): 448-452. doi: 10.1073/pnas.1410088112.

Euskirchen, E.S., Bret-Harte, M.S., Scott, G.J., Edgar, C., and Shaver, G.R. 2012. Seasonal patterns of carbon dioxide and water fluxes in three representative tundra ecosystems in northern Alaska. Ecosphere 3(1): 1-19. doi: 10.1890/ES11-00202.1.

Euskirchen, E.S., Bret-Harte, M.S., Shaver, G.R., Edgar, C.W., and Romanovsky, V.E. 2017. Long-term release of carbon dioxide from Arctic Tundra ecosystems in Alaska. Ecosystems 20(5): 960-974. doi: 10.1007/s10021-016-0085-9.

Fahnestock, J.T., Jones, M.H., Brooks, P.D., Walker, D.A., and Welker, J.M. 1998. Winter and early spring $\mathrm{CO}_{2}$ efflux from tundra communities of northern Alaska. J. Geophys. Res. Atmos. 103(D22): 29023-29027. doi: 10.1029/ 98JD00805. 
Fahnestock, J.T., Jones, M.H., Brooks, P.D., and Welker, J.M. 1999a. Significant $\mathrm{CO}_{2}$ emissions from tundra soils during winter: implications for annual carbon budgets of arctic communities. Global Biogeochem. Cycles 13: 775-779. doi: 10.1029/1999GB900006.

Fahnestock, J.T., Jones, M.H., and Welker, J.M. 1999b. Wintertime $\mathrm{CO}_{2}$ efflux from arctic soils: implications for annual carbon budgets. Global Biogeochem. Cycles 13(3): 775-779. doi: 10.1029/1999GB900006.

Farrer, E.C., Ashton, I.W., Spasojevic, M.J., Fu, S.Y., Gonzalez, D.J.X., and Suding, K.N. 2015. Indirect effects of global change accumulate to alter plant diversity but not ecosystem function in alpine tundra. J. Ecol. 103(2): 351-360. doi: $10.1111 / 1365-2745.12363$.

Flanner, M.G., and Zender, C.S. 2006. Linking snowpack microphysics and albedo evolution. J. Geophys. Res. Atmos. 111(D12). doi: 10.1029/2005JD006834.

Forbes, B.C., Kumpula, T., Meschtyb, N., Laptander, R., Macias-Fauria, M., Zetterberg, P., et al. 2016. Sea ice, rainon-snow and tundra reindeer nomadism in Arctic Russia. Biol. Lett. 12(11): 20160466. doi: 10.1098/rsbl.2016.0466.

Formica, A., Farrer, E.C., Ashton, I.W., and Suding, K.N. 2014. Shrub expansion over the past 62 years in Rocky Mountain alpine tundra: possible causes and consequences. Arct. Antarct. Alp. Res. 46(3): 616-631. doi: 10.1657| 1938-4246-46.3.616.

Forrest, J.R.K. 2015. Plant-pollinator interactions and phenological change: what can we learn about climate impacts from experiments and observations? Oikos 124(1): 4-13. doi: 10.1111/oik.01386.

Francon, L., Corona, C., Till-Bottraud, I., Choler, P., Carlson, B.Z., Charrier, G., et al. 2020. Assessing the effects of earlier snow melt-out on alpine shrub growth: the sooner the better? Ecol. Indic. 115: 106455. doi: 10.1016/ j.ecolind.2020.106455.

Fraser, R.H., Olthof, I., Lantz, T.C., and Schmitt, C. 2016. UAV photogrammetry for mapping vegetation in the lowArctic. Arct. Sci. 2(3): 79-102. doi: 10.1139/as-2016-0008.

Frei, E.R., and Henry, G.R.H. 2021. Long-term effects of snowmelt timing and climate warming on phenology, growth, and reproductive effort of Arctic tundra plant species. Arct. Sci. doi: 10.1139/as-2021-0028.

Friedel, H. 1961. Schneedeckendauer und Vegetationsverteilungen im Gelände. (Snow cover duration and vegetation patterns in alpine terrain.). Mitt. Forstl. Bundes-Versuchsanst. Mariabrunn (Wien). 59: 317-369.

Garibaldi, M.C., Bonnaventure, P.P., and Lamoureux, S.F. 2021. Utilizing the TTOP model to understand spatial permafrost temperature variability in a High Arctic landscape, Cape Bounty, Nunavut, Canada. Permafr. Periglac. Process. 32(1): 19-34. doi: 10.1002/ppp.2086.

Gehrmann, F., Hanninen, H., Liu, C., and Saarinen, T. 2017. Phenological responses to small-scale spatial variation in snowmelt timing reveal compensatory and conservative strategies in subarctic-alpine plants. Plant Ecol. Divers. 10(5-6): 453-468. doi: 10.1080/17550874.2018.1428693.

Gehrmann, F., Ziegler, C., and Cooper, E.J. 2022. Natural and experimental snowmelt gradients have a similar effect on the onset and rate of autumn senescence in High Arctic plants. Arct. Sci. doi: 10.1139/as-2020-0044.

Gilg, O., Sittler, B., and Hanski, I. 2009. Climate change and cyclic predator-prey population dynamics in the high Arctic. Global Change Biol. 15(11): 2634-2652. doi: 10.1111/j.1365-2486.2009.01927.x.

Gillespie, M.A.K., Baggesen, N., and Cooper, E.J. 2016. High Arctic flowering phenology and plant-pollinator interactions in response to delayed snow melt and simulated warming. Environ. Res. Lett. 11(11)115006. doi: 10.1088/ 1748-9326/11/11/115006.

Gillespie, M.A.K., and Cooper, E.J. 2021. The seasonal dynamics of a High Arctic plant-visitor network: temporal observations and responses to delayed snow melt. Arct. Sci. doi: 10.1139/as-2020-0056.

Gisnås, K., Westermann, S., Schuler, T.V., Melvold, K., and Etzelmuller, B. 2016. Small-scale variation of snow in a regional permafrost model. Cryosphere 10(3): 1201-1215. doi:10.5194/tc-10-1201-2016.

Goodrich, L.E. 1982. The influence of the snow cover on the ground thermal regime. Can. Geotech. J. 19: 421-432. doi: 10.1139/t82-047.

Granberg, H.B. 1988. On the spatial dynamics of snowcover - permafrost relationships at Schefferville. In Proceedings of the 5th International Conference on Permafrost, Trondheim, Norway. Tapir Publishers, Trondheim, Norway. pp. 159-164.

Gray, A., Krolikowski, M., Fretwell, P., Convey, P., Peck, L.S., Mendelova, M., Smith, A.G., and Davey, M.P. 2020. Remote sensing reveals Antarctic green snow algae as important terrestrial carbon sink. Nat. Commun. 11: 2527. doi: 10.1038/s41467-020-16018-w.

Green, K. 2010. Alpine taxa exhibit differing responses to climate warming in the Snowy Mountains of Australia. J. Mt. Sci. 7(2): 167-175. doi: 10.1007/s11629-010-1115-2.

Green, K., and Pickering, C. 2009. Vegetation, microclimate and soils associated with the latest-lying snowpatches in Australia. Plant Ecol. Divers. 2(3): 289-300. doi: 10.1080/17550870903019275.

Groffman, P.M., Driscoll, C.T., Fahey, T.J., Hardy, J.P., Fitzhugh, R.D., and Tierney, G.L. 2001. Colder soils in a warmer world: a snow manipulation study in a northern hardwood forest ecosystem. Biogeochemistry 56(2): 135-150. doi: 10.1023/A:1013039830323.

Grogan, P. 2012. Cold Season Respiration across a Low Arctic Landscape: the influence of vegetation type, snow depth, and interannual climatic variation. Arct. Antarct. Alp. Res. 44(4): 446-456. doi: 10.1657/1938-4246-44.4.446.

Grogan, P., and Jonasson, S. 2005. Temperature and substrate controls on intra-annual variation in ecosystem respiration in two subarctic vegetation types. Global Change Biol. 11(3): 465-475. doi: 10.1111/j.1365-2486.2005.00912.x.

Grünberg, I., Wilcox, E.J., Zwieback, S., Marsh, P., and Boike, J. 2020. Linking tundra vegetation, snow, soil temperature, and permafrost. Biogeosciences 17(16): 4261-4279. doi: 10.5194/bg-17-4261-2020.

Grundstein, A., Todhunter, P., and Mote, T. 2005. Snowpack control over the thermal offset of air and soil temperatures in eastern North Dakota. Geophys. Res. Lett. 32(8). doi: 10.1029/2005GL022532. 
Haeberli, W. 1973. Die Basistemperatur der winterlichen Schneedecke als möglicher Indikator für die Verbreitung von Permafrost in den Alpen. Zeitschrift für Gletscherkunde und Glazialgeologie. 9(1-2): 221-227.

Hakkarainen, H., Virtanen, R., Honkanen, J.O., and Roininen, H. 2007. Willow bud and shoot foraging by ptarmigan in relation to snow level in NW Finnish Lapland. Polar Biol. 30(5): 619-624. doi: 10.1007/s00300-006-0221-7.

Hall, D.K., Riggs, G.A., Salomonson, V.V., DiGirolamo, N.E., and Bayr, K.J. 2002. MODIS snow-cover products. Remote Sens. Environ. 83(1-2): 181-194. doi: 10.1016/S0034-4257(02)00095-0.

Hallet, B., and Prestrud, S. 1986. Dynamics of periglacial sorted circles in western Spitsbergen. Quatern. Res. 26(1): 81-99. doi: 10.1016/0033-5894(86)90085-2.

Hansen, B.B., Grotan, V., Aanes, R., Saether, B.E., Stien, A., Fuglei, E., et al. 2013. Climate events synchronize the dynamics of a resident vertebrate community in the High Arctic. Science 339(6117): 313-315. doi: 10.1126/ science.1226766.

Hansen, B.B., Isaksen, K., Benestad, R.E., Kohler, J., Pedersen, A.O., Loe, L.E., et al. 2014. Warmer and wetter winters: characteristics and implications of an extreme weather event in the High Arctic. Environ. Res. Lett. 9(11): 114021. doi: 10.1088/1748-9326/9/11/114021.

Hansen, B.B., Lorentzen, J.R., Welker, J.M., Varpe, O., Aanes, R., Beumer, L.T., and Pedersen, A.O. 2019. Reindeer turning maritime: ice-locked tundra triggers changes in dietary niche utilization. Ecosphere 10(4): e02672. doi: 10.1002/ecs2.2672.

Harder, P., Pomeroy, J.W., and Helgason, W.D. 2020. Improving sub-canopy snow depth mapping with unmanned aerial vehicles: lidar versus structure-from-motion techniques. Cryosphere 14(6): 1919-1935. doi: 10.5194/tc-141919-2020.

Harte, J. 2019. Reflections on 27 years of ecosystem warming. In Ecosystem consequences of soil warming. Edited by J.E. Mohan. Elsevier. pp. 2-27.

Harte, J., Saleska, S.R., and Levy, C. 2015. Convergent ecosystem responses to 23-year ambient and manipulated warming link advancing snowmelt and shrub encroachment to transient and long-term climate-soil carbon feedback. Global Change Biol. 21(6): 2349-2356. doi: 10.1111/gcb.12831.

Harte, J., and Shaw, R. 1995. Shifting dominance within a montane vegetation community - results of a climatewarming experiment. Science 267(5199): 876-880. doi: 10.1126/science.267.5199.876.

Harte, J., Torn, M.S., Chang, F.R., Feifarek, B., Kinzig, A.P., Shaw, R., and Shen, K. 1995. Global warming and soil microclimate - results from a meadow-warming experiment. Ecol. Appl. 5(1): 132-150. doi: 10.2307/1942058.

Hegland, S.J., Nielsen, A., Lazaro, A., Bjerknes, A.L., and Totland, O. 2009. How does climate warming affect plantpollinator interactions? Ecol. Lett. 12(2): 184-195. doi: 10.1111/j.1461-0248.2008.01269.x.

Hijmans, R.J. 2021. raster: geographic data analysis and modeling. R package version 3.4-13. Available from https:// CRAN.R-project.org/package=raster.

Hobbie, S.E., and Chapin, F.S. 1996. Winter regulation of tundra litter carbon and nitrogen dynamics. Biogeochemistry 35(2): 327-338. doi: 10.1007/BF02179958.

Horwath, J.L., Sletten, R.S., Hagedorn, B., and Hallet, B. 2008. Spatial and temporal distribution of soil organic carbon in nonsorted striped patterned ground of the High Arctic. J. Geophys. Res.-Biogeosci. 113(G3): G03S07. doi: 10.1029/2007JG000511.

Høye, T.T., and Forchhammer, M.C. 2008. Phenology of high-arctic arthropods: effects of climate on spatial, seasonal, and inter-annual variation. Adv. Ecol. Res. 40: 299-324. doi: 10.1016/s0065-2504(07)00013-x.

Høye, T.T., Post, E., Schmidt, N.M., Trøjelsgaard, K., and Forchhammer, M.C. 2013. Shorter flowering seasons and declining abundance of flower visitors in a warmer Arctic. Nat. Clim. Change 3(8): 759-763. doi: 10.1038/ nclimate1909.

Hsiang, T., Matsumoto, N., and Millett, S.M. 1999. Biology and management of Typhula snow molds of turfgrass. Plant Dis. 83(9): 788-798. doi: 10.1094/PDIS.1999.83.9.788.

Hülber, K., Winkler, M., and Grabherr, G. 2010. Intraseasonal climate and habitat-specific variability controls the flowering phenology of high alpine plant species. Funct. Ecol. 24(2): 245-252. doi: 10.1111/j.1365-2435.2009.01645.x.

Jabis, M.D., Germino, M.J., and Kueppers, L.M. 2020a. Colonisation of the alpine tundra by trees: alpine neighbours assist late-seral but not early-seral conifer seedlings. Plant Ecol. Divers. 13(3-4): 209-224. doi: 10.1080/ 17550874.2020.1762134.

Jabis, M.D., Winkler, D.E., and Kueppers, L.M. 2020b. Warming acts through earlier snowmelt to advance but not extend alpine community flowering. Ecology 101(9): e03108. doi: 10.1002/ecy.3108.

Jan, A., and Painter, S.L. 2020. Permafrost thermal conditions are sensitive to shifts in snow timing. Environ. Res. Lett. 15(8): 084026. doi: 10.1088/1748-9326/ab8ec4.

Jespersen, R.G., Leffler, A.J., Oberbauer, S.F., and Welker, J.M. 2018. Arctic plant ecophysiology and water source utilization in response to altered snow: isotopic $\left(\delta^{18} \mathrm{O}\right.$ and $\left.\delta^{2} \mathrm{H}\right)$ evidence for meltwater subsidies to deciduous shrubs. Oecologia 187(4): 1009-1023. doi: 10.1007/s00442-018-4196-1.

Johansson, M., Callaghan, T.V., Bosio, J., Akerman, H.J., Jackowicz-Korczynski, M., and Christensen, T.R. 2013. Rapid responses of permafrost and vegetation to experimentally increased snow cover in sub-arctic Sweden. Environ. Res. Lett. 8(3): 035025. doi: 10.1088/1748-9326/8/3/035025.

Jones, H.G., Pomeroy, J.W., Walker, D.A., and Hoham, R.W. 2001. Snow ecology. 1st ed. Press Syndicate of the University of Cambridge, Cambridge University Press. 378 p.

Jones, M.H., Fahnestock, J.T., Walker, D.A., Walker, M.D., and Welker, J.M. 1998. Carbon dioxide fluxes in moist and dry arctic tundra during season: responses to increases in summer temperature and winter snow accumulation. Arct. Alp. Res. 30(4): 373-380. doi: 10.1080/00040851.1998.12002912. 
Jones, M.H., Fahnestock, J.T., and Welker, J.M. 1999. Early and late winter $\mathrm{CO}_{2}$ efflux from arctic tundra in the Kuparuk River watershed, Alaska, USA. Arct. Antarct. Alp. Res. 31(2): 187-190. doi: 10.1080/15230430.1999.12003296.

Ju, J.C., and Masek, J.G. 2016. The vegetation greenness trend in Canada and US Alaska from 1984-2012 Landsat data. Remote Sens. Environ. 176: 1-16. doi: 10.1016/j.rse.2016.01.001.

Kameyama, Y., and Kudo, G. 2009. Flowering phenology influences seed production and outcrossing rate in populations of an alpine snowbed shrub, Phyllodoce aleutica: effects of pollinators and self-incompatibility. Ann. Bot. 103(9): 1385-1394. doi: 10.1093/aob/mcp037.

Kankaanpää, T., Skov, K., Abrego, N., Lund, M., Schmidt, N.M., and Roslin, T. 2018. Spatiotemporal snowmelt patterns within a high Arctic landscape, with implications for flora and fauna. Arct. Antarct. Alp. Res. 50(1): e1415624. doi: 10.1080/15230430.2017.1415624.

Karlsen, S.R., Stendardi, L., Tommervik, H., Nilsen, L., Arntzen, I., and Cooper, E.J. 2021. Time-series of cloud-free sentinel-2 NDVI data used in mapping the onset of growth of central Spitsbergen, Svalbard. Remote Sens. 13(15): 3031. doi:10.3390/rs13153031.

Kausrud, K.L., Mysterud, A., Steen, H., Vik, J.O., Ostbye, E., Cazelles, B., et al. 2008. Linking climate change to lemming cycles. Nature 456(7218): 93-97. doi: 10.1038/nature07442.

Kearney, M.R. 2020. How will snow alter exposure of organisms to cold stress under climate warming? Global Ecol. Biogeogr. 29(7): 1246-1256. doi: 10.1111/geb.13100.

Keller, F., and Körner, C. 2003. The role of photoperiodism in alpine plant development. Arct. Antarct. Alp. Res. 35(3): 361-368. doi: 10.1657/1523-0430(2003)035[0361:TROPIA]2.0.CO;2.

Kelsey, K.C., Pedersen, S.H., Leffler, A.J., Sexton, J.O., Feng, M., and Welker, J.M. 2021. Winter snow and spring temperature have differential effects on vegetation phenology and productivity across Arctic plant communities. Global Change Biol. 27(8): 1572-1586. doi: 10.1111/gcb.15505.

Kessler, M.A., and Werner, B.T. 2003. Self-organization of sorted patterned ground. Science 299(5605): 380-383. doi: $10.1126 /$ science.1077309.

Klein, G., Rebetez, M., Rixen, C., and Vitasse, Y. 2018. Unchanged risk of frost exposure for subalpine and alpine plants after snowmelt in Switzerland despite climate warming. Int. J. Biometeorol. 62(9): 1755-1762. doi: 10.1007/s00484-018-1578-3.

Klein, G., Vitasse, Y., Rixen, C., Marty, C., and Rebetez, M. 2016. Shorter snow cover duration since 1970 in the Swiss Alps due to earlier snowmelt more than to later snow onset. Clim. Change 139(3-4): 637-649. doi: 10.1007/s10584016-1806-y.

Klinges, D.H., and Scheffers, B.R. 2021. Microgeography, not just latitude, drives climate overlap on mountains from tropical to polar ecosystems. Am. Nat. 197(1): 75-92. doi: 10.1086/711873.

Körner, C. 2003. Alpine plant life. 2nd ed. Springer Verlag, Berlin. 344 p.

Körner, C., Riedl, S., Keplinger, T., Richter, A., Wiesenbauer, J., Schweingruber, F., and Hiltbrunner, E. 2019. Life at $0{ }^{\circ} \mathrm{C}$ : the biology of the alpine snowbed plant Soldanella pusilla. Alp. Bot. 129(2): 63-80. doi: 10.1007/s00035-01900220-8.

Korslund, L., and Steen, H. 2006. Small rodent winter survival: snow conditions limit access to food resources. J. Anim. Ecol. 75(1): 156-166. doi: 10.1111/j.1365-2656.2005.01031.x.

Kreyling, J. 2019. The ecological importance of winter in temperate, boreal and arctic ecosystems in times of climate change. In Progress in botany. Edited by F.M. Cánovas, U. Lüttge, C. Leuschner, and M.-C. Risueño. Springer, Berlin, Heidelberg. p. 377-399

Kropp, H., Loranty, M.M., Natali, S.M., Kholodov, A.L., Rocha, A.V., Myers-Smith, I., et al. 2021. Shallow soils are warmer under trees and tall shrubs across Arctic and Boreal ecosystems. Environ. Res. Lett. 16(1): 015001. doi: $10.1088 / 1748-9326 /$ abc994.

Kudo, G. 2016. Structure and function of mountain ecosystems in Japan ecological research monographs biodiversity and vulnerability to climate change preface. In Structure and function of mountain ecosystems in Japan: biodiversity and vulnerability to climate change. Edited by G. Kudo. Ecological Research Monographs. pp. V-VI.

Kudo, G., and Cooper, E.J. 2019. When spring ephemerals fail to meet pollinators: mechanism of phenological mismatch and its impact on plant reproduction. Proc. R. Soc. B. Biol. Sci. 286(1904): 20190573. doi: 10.1098/ rspb.2019.0573.

Kudo, G., Hirao, A.S., and Kawai, Y. 2011. Pollination efficiency of bumblebee queens and workers in the alpine shrub Rhododendron aureum. Int. J. Plant Sci. 172(1): 70-77. doi:10.1086/657282.

Kudo, G., and Ida, T.Y. 2013. Early onset of spring increases the phenological mismatch between plants and pollinators. Ecology 94(10): 2311-2320. doi: 10.1890/12-2003.1.

Kuhn, M. 2001. The nutrient cycle through snow and ice, a review. Aquat. Sci. 63(2): 150-167. doi: 10.1007/ PL00001348.

Lafrenière, M.J., Laurin, E., and Lamoureux, S.F. 2013. The impact of snow accumulation on the active layer thermal regime in high Arctic soils. Vadose Zone J. 12(1): 1-13. doi: 10.2136/vzj2012.0058.

Larcher, W., and Siegwolf, R. 1985. Development of acute frost drought in Rhododendron ferrugineum at the alpine timberline. Oecologia 67(2): 298-300. doi: 10.1007/BF00384304.

Layton-Matthews, K., Hansen, B.B., Grotan, V., Fuglei, E., and Loonen, M. 2020. Contrasting consequences of climate change for migratory geese: predation, density dependence and carryover effects offset benefits of high-arctic warming. Global Change Biol. 26(2): 642-657. doi: 10.1111/gcb.14773.

Le Moullec, M., Pedersen, A.O., Stien, A., Rosvold, J., and Hansen, B.B. 2019. A century of conservation: the ongoing recovery of Svalbard reindeer. J. Wildl. Manage. 83(8): 1676-1686. doi: 10.1002/jwmg.21761. 
Leffler, A.J., Klein, E.S., Oberbauer, S.F., and Welker, J.M. 2016. Coupled long-term summer warming and deeper snow alters species composition and stimulates gross primary productivity in tussock tundra. Oecologia 181(1): 287-297. doi: 10.1007/s00442-015-3543-8.

Lewkowicz, A.G. 2008. Evaluation of miniature temperature-loggers to monitor snowpack evolution at mountain permafrost sites, northwestern Canada. Permafr. Periglac. Process. 19: 323-331. doi: 10.1002/ppp.625.

Liang, H., Huang, X.D., Sun, Y.H., Wang, Y.L., and Liang, T.G. 2017. Fractional snow-cover mapping based on MODIS and UAV data over the Tibetan Plateau. Remote Sens. 9(12): 1332. doi: 10.3390/rs9121332.

Lilbaek, G., and Pomeroy, J.W. 2008. Ion enrichment of snowmelt runoff water caused by basal ice formation. Hydrol. Process. 22(15): 2758-2766. doi: 10.1002/hyp.7028.

Liston, G.E., McFadden, J.P., Sturm, M., and Pielke, R.A. 2002. Modelled changes in arctic tundra snow, energy and moisture fluxes due to increased shrubs. Global Change Biol. 8(1): 17-32. doi: 10.1046/j.1354-1013.2001.00416.x.

Liston, G.E., and Sturm, M. 2002. Winter precipitation patterns in arctic Alaska determined from a blowing-snow model and snow-depth observations. J. Hydrometeorol. 3(6): 646-659. doi: 10.1175/1525-7541(2002)003<0646: WPPIAA $>2.0 . C O ; 2$.

Little, C.J., Wheeler, J.A., Sedlacek, J., Cortes, A.J., and Rixen, C. 2016. Small-scale drivers: the importance of nutrient availability and snowmelt timing on performance of the alpine shrub Salix herbacea. Oecologia 180(4): 1015-1024. doi: 10.1007/s00442-015-3394-3.

Livensperger, C., Steltzer, H., Darrouzet-Nardi, A., Sullivan, P.F., Wallenstein, M., and Weintraub, M.N. 2016. Earlier snowmelt and warming lead to earlier but not necessarily more plant growth. AoB Plants, 8: plw021. doi: 10.1093/ aobpla/plw021.

Lopez-Moreno, J.I., Revuelto, J., Gilaberte, M., Moran-Tejeda, E., Pons, M., Jover, E., et al. 2014. The effect of slope aspect on the response of snowpack to climate warming in the Pyrenees. Theor. Appl. Climatol. 117(1-2): 207-219. doi: 10.1007/s00704-013-0991-0.

Loranty, M.M., Goetz, S.J., and Beck, P.S.A. 2011. Tundra vegetation effects on pan-Arctic albedo. Environ. Res. Lett. 6(2): 024014. doi: 10.1088/1748-9326/6/2/024014.

Maclean, S.F., and Pitelka, F.A. 1971. Seasonal patterns of abundance of tundra arthropods near Barrow. Arctic 24(1): 19.

Makoto, K., Kajimoto, T., Koyama, L., Kudo, G., Shibata, H., Yanai, Y., and Cornelissen, J.H.C. 2014. Winter climate change in plant-soil systems: summary of recent findings and future perspectives. Ecol. Res. 29(4): 593-606. doi: $10.1007 / \mathrm{s} 11284-013-1115-0$.

Malnes, E., Karlsen, S.R., Johansen, B., Bjerke, J.W., and Tømmervik, H. 2016. Snow season variability in a borealArctic transition area monitored by MODIS data. Environ. Res. Lett. 11(12): 125005. doi: 10.1088/1748-9326/11/12/ 125005.

Mark, A.F., Korsten, A.C., Guevara, D.U., Dickinson, K.J.M., Humar-Maegli, T., Michel, P., et al. 2015. Ecological responses to 52 years of experimental snow manipulation in high-alpine cushionfield, Old Man Range, southcentral New Zealand. Arct. Antarct. Alp. Res. 47(4): 751-772. doi: 10.1657/AAAR0014-098.

Marsh, P., Pomeroy, J.W., and Neumann, N. 1997. Sensible heat flux and local advection over a heterogeneous landscape at an Arctic tundra site during snowmelt. In Annals of glaciology, Vol. 25, 1997: papers from the international symposium on representation of the cryosphere in climate and hydrological models held at Victoria, British Columbia, Canada, 12-15 August 1996. Vol. 25. Edited by J.E. Walsh. Annals of Glaciology. pp. 132-136.

Marty, C. 2008. Regime shift of snow days in Switzerland. Geophys. Res. Lett. 35(12): L12501. doi: 10.1029/ 2008GL033998.

Matsumoto, N. 2009. Snow molds: a group of fungi that prevail under snow. Microbes Environ. 24(1): 14-20. doi: 10.1264/jsme2.ME09101.

Maurer, J. 2007. Atlas of the cryosphere. National Snow and Ice Data Center. Digital Media, Boulder, Colorado, USA.

McKinney, A.M., CaraDonna, P.J., Inouye, D.W., Barr, B., Bertelsen, C.D., and Waser, N.M. 2012. Asynchronous changes in phenology of migrating Broad-tailed Hummingbirds and their early-season nectar resources. Ecology 93(9): 1987-1993. doi: 10.1890/12-0255.1.

Memmott, J., Craze, P.G., Waser, N.M., and Price, M.V. 2007. Global warming and the disruption of plant-pollinator interactions. Ecol. Lett. 10(8): 710-717. doi: 10.1111/j.1461-0248.2007.01061.x.

Mikan, C.J., Schimel, J.P., and Doyle, A.P. 2002. Temperature controls of microbial respiration in arctic tundra soils above and below freezing. Soil Biol. Biochem. 34(11): 1785-1795. doi: 10.1016/S0038-0717(02)00168-2.

Milner, J.M., Varpe, O., van der Wal, R., and Hansen, B.B. 2016. Experimental icing affects growth, mortality, and flowering in a high Arctic dwarf shrub. Ecol. Evol. 6(7): 2139-2148. doi: 10.1002/ece3.2023.

Morgner, E., Elberling, B., Strebel, D., and Cooper, E.J. 2010. The importance of winter in annual ecosystem respiration in the High Arctic: effects of snow depth in two vegetation types. Polar Res. 29(1): 58-74. doi: 10.1111/j.17518369.2010.00151.x.

Moriana-Armendariz, M., Abbandonato, H., Yamaguchi, T., Mörsdorf, M.A., Aares, K.A., Semenchuk, P.R., Tojo, M., and Cooper, E.J. 2021. Increased snow and cold season temperatures alter High Arctic parasitic fungi-host plant interactions. Arct. Sci. doi: 10.1139/as-2020-0027.

Moriana-Armendariz, M., Nilsen, L., and Cooper, E.J. 2022. Natural variation in snow depth and snow melt timing in the High Arctic have implications for soil and plant nutrient status and vegetation composition. Arct. Sci. doi: $10.1139 /$ as-2020-0025.

Moriwaki, H., Takyu, M., and Kameyama, Y. 2020. Temporal variations in the linkages between plants and flower visitors and the pollination success of Primula modesta along the snowmelt gradient. Nord. J. Bot. 38(5). doi: 10.1111/njb.02632. 
Mörsdorf, M.A., Baggesen, N.S., Yoccoz, N.G., Michelsen, A., Elberling, B., Ambus, P.L., and Cooper, E.J. 2019. Deepened winter snow significantly influences the availability and forms of nitrogen taken up by plants in High Arctic tundra. Soil Biol. Biochem. 135: 222-234. doi: 10.1016/j.soilbio.2019.05.009.

Myers-Smith, I., Forbes, B.C., Wilmking, M., Hallinger, M., Lantz, T., Blok, D., et al. 2011. Shrub expansion in tundra ecosystems: dynamics, impacts and research priorities. Environ. Res. Lett.6: 045509. doi: 10.1088/1748-9326/6/4/ 045509.

Myers-Smith, I.H., Elmendorf, S.C., Beck, P.S.A., Wilmking, M., Hallinger, M., Blok, D., et al. 2015. Climate sensitivity of shrub growth across the tundra biome. Nat. Clim. Change 5(9): 887. doi: 10.1038/nclimate2697.

Myers-Smith, I.H., Grabowski, M.M., Thomas, H.J.D., Angers-Blondin, S., Daskalova, G.N., Bjorkman, A.D., et al. 2019. Eighteen years of ecological monitoring reveals multiple lines of evidence for tundra vegetation change. Ecol. Monogr. 89(2): e01351. doi: 10.1002/ecm.1351.

Myers-Smith, I.H., and Hik, D.S. 2013. Shrub canopies influence soil temperatures but not nutrient dynamics: An experimental test of tundra snow-shrub interactions. Ecol. Evol. 3(11): 3683-3700. doi: 10.1002/ece3.710.

Myers-Smith, I.H., Kerby, J.T., Phoenix, G.K., Bjerke, J.W., Epstein, H.E., Assmann, J.J., et al. 2020. Complexity revealed in the greening of the Arctic. Nat. Clim. Change 10(2): 106-117. doi: 10.1038/s41558-019-0688-1.

Nagler, T., Rott, H., Malcher, P., and Muller, F. 2008. Assimilation of meteorological and remote sensing data for snowmelt runoff forecasting. Remote Sens. Environ. 112(4): 1408-1420. doi: 10.1016/j.rse.2007.07.006.

Natali, S.M., Schuur, E.A.G., Mauritz, M., Schade, J.D., Celis, G., Crummer, K.G., et al. 2015. Permafrost thaw and soil moisture driving $\mathrm{CO}_{2}$ and $\mathrm{CH}_{4}$ release from upland tundra. J. Geophys. Res. Biogeosci. 120(3): 525-537. doi: 10.1002/2014JG002872.

Natali, S.M., Schuur, E.A.G., Webb, E.E., Pries, C.E.H., and Crummer, K.G. 2014. Permafrost degradation stimulates carbon loss from experimentally warmed tundra. Ecology 95(3): 602-608. doi: 10.1890/13-0602.1.

Natali, S.M., Watts, J.D., Rogers, B.M., Potter, S., Ludwig, S.M., Selbmann, A.K., et al. 2019. Large loss of $\mathrm{CO}_{2}$ in winter observed across the northern permafrost region. Nat. Clim. Change 9(11): 852. doi: 10.1038/s41558-019-0592-8.

Niedzielski, T., Szymanowski, M., Mizinski, B., Spallek, W., Witek-Kasprzak, M., Slopek, J., et al. 2019. Estimating snow water equivalent using unmanned aerial vehicles for determining snow-melt runoff. J. Hydrol. 578: 124046. doi: 10.1016/j.jhydrol.2019.124046.

Niittynen, P., Heikkinen, R.K., and Luoto, M. 2018. Snow cover is a neglected driver of Arctic biodiversity loss. Nat. Clim. Change. 8(11): 997. doi: 10.1038/s41558-018-0311-x.

Nobrega, S., and Grogan, P. 2007. Deeper snow enhances winter respiration from both plant-associated and bulk soil carbon pools in birch hummock tundra. Ecosystems 10(3): 419-431. doi: 10.1007/s10021-007-9033-z.

Notaro, M., Bennington, V., and Vavrus, S. 2015. Dynamically downscaled projections of lake-effect snow in the Great Lakes Basin. J. Clim. 28(4): 1661-1684. doi: 10.1175/JCLI-D-14-00467.1.

Notaro, M., Lorenz, D., Hoving, C., and Schummer, M. 2014. Twenty-first-century projections of snowfall and winter severity across central-eastern North America. J. Clim. 27(17): 6526-6550. doi: 10.1175/JCLI-D-13-00520.1.

Nowinski, N.S., Taneva, L., Trumbore, S.E., and Welker, J.M. 2010. Decomposition of old organic matter as a result of deeper active layers in a snow depth manipulation experiment. Oecologia 163(3): 785-792. doi: 10.1007/s00442009-1556-x.

Oberbauer, S.F., Starr, G., and Pop, E.W. 1998. Effects of extended growing season and soil warming on carbon dioxide and methane exchange of tussock tundra in Alaska. J. Geophys. Res. Atmos. 103(D22): 29075-29082. doi: 10.1029/98JD00522.

Oechel, W.C., Vourlitis, G., and Hastings, S.J. 1997. Cold season $\mathrm{CO}_{2}$ emission from arctic soils. Global Biogeochem. Cycles 11(2): 163-172. doi: 10.1029/96GB03035.

Ogilvie, J.E., Griffin, S.R., Gezon, Z.J., Inouye, B.D., Underwood, N., Inouye, D.W., and Irwin, R.E. 2017. Interannual bumble bee abundance is driven by indirect climate effects on floral resource phenology. Ecol. Lett. 20(12): 1507-1515. doi: 10.1111/ele.12854.

Olofsson, J., Ericson, L., Torp, M., Stark, S., and Baxter, R. 2011. Carbon balance of Arctic tundra under increased snow cover mediated by a plant pathogen. Nat. Clim. Change 1(4): 220-223. doi: 10.1038/nclimate1142.

Öquist, M.G., Sparrman, T., Klemedtsson, L., Drotz, S.H., Grip, H., Schleucher, J., and Nilsson, M. 2009. Water availability controls microbial temperature responses in frozen soil $\mathrm{CO}_{2}$ production. Global Change Biol. 15(11): 2715-2722. doi: 10.1111/j.1365-2486.2009.01898.x.

Panetta, A.M., Stanton, M.L., and Harte, J. 2018. Climate warming drives local extinction: evidence from observation and experimentation. Sci. Adv. 4(2). doi: 10.1126/sciadv.aaq1819.

Parmentier, F.J.W., Nilsen, L., Tommervik, H., and Cooper, E.J. 2021. A distributed time-lapse camera network to track vegetation phenology with high temporal detail and at varying scales. Earth Syst. Sci. Data 13(7): 3593-3606. doi: 10.5194/essd-13-3593-2021.

Pattison, R.R., and Welker, J.M. 2014. Differential ecophysiological response of deciduous shrubs and a graminoid to long-term experimental snow reductions and additions in moist acidic tundra, Northern Alaska. Oecologia 174(2): 339-350. doi: 10.1007/s00442-013-2777-6.

Pedersen, A.O., Lier, M., Routti, H., Christiansen, H.H., and Fuglei, E. 2006. Co-feeding between Svalbard rock ptarmigan (Lagopus muta hyperborea) and Svalbard reindeer (Rangifer tarandus platyrhynchus). Arctic 59(1): 61-64.

Pedersen, A.O., Tombre, I., Jepsen, J.U., Eidesen, P.B., Fuglei, E., and Stien, A. 2013. Spatial patterns of goose grubbing suggest elevated grubbing in dry habitats linked to early snowmelt. Polar Res. 32: 19719. doi: 10.3402/ polar.v32i0.19719. 
Pedersen, S.H., Bentzen, T.W., Reinking, A.K., Liston, G.E., Elder, K., Lenart, E.A., et al. 2021. Quantifying effects of snow depth on caribou winter range selection and movement in Arctic Alaska. Mov. Ecol. 9(1): 48. doi: 10.1186/ s40462-021-00276-4.

Pedersen, S.H., Liston, G.E., Tamstorf, M.P., Abermann, J., Lund, M., and Schmidt, N.M. 2018. Quantifying snow controls on vegetation greenness. Ecosphere 9(6): e02309. doi: 10.1002/ecs2.2309.

Pedron, S., Xu, X., Walker, J.C., Ferguson, J.C., Jespersen, R.G., Welker, J.M., Klein, E.S., and Czimczik, C.I. 2021. Time-integrated collection of $\mathrm{CO}_{2}$ for ${ }^{14} \mathrm{C}$ analysis from soils. Radiocarbon 63(4): 1303-1319. doi: 10.1017/ RDC.2021.42.

Pelletier, M., Allard, M., and Levesque, E. 2019. Ecosystem changes across a gradient of permafrost degradation in subarctic Québec (Tasiapik Valley, Nunavik, Canada). Arct. Sci. 5: 1-26. doi: 10.1139/as-2016-0049.

Pickering, C., Green, K., Barros, A.A., and Venn, S. 2014. A resurvey of late-lying snowpatches reveals changes in both species and functional composition across snowmelt zones. Alp. Bot. 124(2): 93-103. doi: 10.1007/s00035014-0140-0.

Pold, G., Baillargeon, N., Lepe, A., Rastetter, E.B., and Sistla, S.A. 2021. Warming effects on arctic tundra biogeochemistry are limited but habitat-dependent: a meta-analysis. Ecosphere 12(10): e03777. doi: 10.1002/ecs2.3777.

Preece, C., Callaghan, T.V., and Phoenix, G.K. 2012. Impacts of winter icing events on the growth, phenology and physiology of sub-arctic dwarf shrubs. Physiol. Plant. 146(4): 460-472. doi: 10.1111/j.1399-3054.2012.01640.x.

Prevey, J., Vellend, M., Ruger, N., Hollister, R.D., Bjorkman, A.D., Myers-Smith, I.H., et al. 2017. Greater temperature sensitivity of plant phenology at colder sites: implications for convergence across northern latitudes. Global Change Biol. 23(7): 2660-2671. doi: 10.1111/gcb.13619.

Prevey, J.S., Rixen, C., Ruger, N., Hoye, T.T., Bjorkman, A.D., Myers-Smith, I.H., et al. 2019. Warming shortens flowering seasons of tundra plant communities. Nat. Ecol. Evol. 3(1): 45-52. doi: 10.1038/s41559-018-0745-6.

Pruitt, W.O. 1957. Observations on the bioclimate of some taiga mammals. Arctic 10: 130-138. doi: 10.14430/ arctic3760.

Pulliainen, J., Luojus, K., Derksen, C., Mudryk, L., Lemmetyinen, J., Salminen, M., et al. 2020. Patterns and trends of Northern hemisphere snow mass from 1980 to 2018. Nature 581: 294-298. doi: 10.1038/s41586-020-2258-0. PMID: 32433620.

Putkonen, J., and Roe, G. 2003. Rain-on-snow events impact soil temperatures and affect ungulate survival. Geophys. Res. Lett. 30(4): 1188. doi: 10.1029/2002GL016326.

Rammig, A., Jonas, T., Zimmermann, N.E., and Rixen, C. 2010. Changes in Alpine plant growth under future climate conditions. Biogeosciences 7(6): 2013-2024. doi: 10.5194/bg-7-2013-2010.

Randin, C.F., Vuissoz, G., Liston, G.E., Vittoz, P., and Guisan, A. 2009. Introduction of snow and geomorphic disturbance variables into predictive models of Alpine plant distribution in the Western Swiss Alps. Arct. Antarct. Alp. Res. 41(3): 347-361. doi: 10.1657/1938-4246-41.3.347.

Reid, D.G., Bilodeau, F., Krebs, C.J., Gauthier, G., Kenney, A.J., Gilbert, B.S., et al. 2012. Lemming winter habitat choice: a snow-fencing experiment. Oecologia 168(4): 935-946. doi: 10.1007/s00442-011-2167-x.

Richert, J.C., Leffler, A.J., Spalinger, D.E., and Welker, J.M. 2021. Snowier winters extend autumn availability of highquality forage for caribou in Arctic Alaska. Ecosphere 12(7): e03617. doi: 10.1002/ecs2.3617.

Ricketts, M.P., Poretsky, R.S., Welker, J.M., and Gonzalez-Meler, M.A. 2016. Soil bacterial community and functional shifts in response to altered snowpack in moist acidic tundra of northern Alaska. Soil 2(3): 459-474. doi: 10.5194/ soil-2-459-2016.

Rieley, G., Welker, J.M., Callaghan, T.V., and Eglinton, G. 1995. Epicuticular Waxes of 2 Arctic species - compositional differences in relation to winter snow cover. Phytochemistry 38(1): 45-52. doi: 10.1016/0031-9422(94)00649-E.

Riseborough, D.W. 2004. Exploring the parameters of a simple model of the permafrost-climate relationship. PhD Thesis. Carleton University, Ottawa.

Riseth, J.A., Tømmervik, H., Helander-Renvall, E., Labba, N., Johansson, C., Malnes, E., et al. 2011. Sami traditional ecological knowledge as a guide to science: snow, ice and reindeer pasture facing climate change. Polar Rec. 47(3): 202-217. doi: 10.1017/S0032247410000434.

Rixen, C. 2020. Phänologische Veränderungen in Hochgebirgen. In Warnsignale Klima - Hochgebirge im Wandel. Edited by J.L. Lozan, S.-W. Breckle, H. Escher-Vetter, H. Grassl, D. Kasang, F. Paul, and U. Schickhoff. Wissenschaftliche Auswertungen, Hamburg, Germany. pp. 220-224.

Rixen, C., Dawes, M.A., Wipf, S., and Hagedorn, F. 2012. Evidence of enhanced freezing damage in treeline plants during six years of $\mathrm{CO}_{2}$ enrichment and soil warming. Oikos 121(10): 1532-1543. doi: 10.1111/j.16000706.2011.20031.x.

Rixen, C., Freppaz, M., Stoeckli, V., Huovinen, C., Huovinen, K., and Wipf, S. 2008. Altered snow density and chemistry change soil nitrogen mineralization and plant growth. Arct. Antarct. Alp. Res. 40(3): 568-575. doi: 10.1657| 1523-0430(07-044)[RIXEN]2.0.CO;2.

Rixen, C., Haeberli, W., and Stoeckli, V. 2004. Ground temperatures under ski pistes with artificial and natural snow. Arct. Antarct. Alp. Res. 36(4): 419-427. doi: 10.1657/1523-0430(2004)036[0419:GTUSPW]2.0.CO;2.

Robinson, S.V.J., and Henry, G.H.R. 2018. High Arctic plants show independent responses to pollination and experimental warming. Botany 96(6): 385-396. doi: 10.1139/cjb-2017-0200.

Rosa, R.K., Oberbauer, S.F., Starr, G., La Puma, I.P., Pop, E., Ahlquist, L., and Baldwin, T. 2015. Plant phenological responses to a long-term experimental extension of growing season and soil warming in the tussock tundra of Alaska. Global Change Biol. 21(12): 4520-4532. doi: 10.1111/gcb.13040.

Roturier, S., and Roué, M. 2009. Of forest, snow and lichen: Sami reindeer herders' knowledge of winter pastures in northern Sweden. For. Ecol. Manage. 258(9): 1960-1967. doi: 10.1016/j.foreco.2009.07.045. 
Roy, B.A., Güsewell, S., and Harte, J. 2004. Response of plant pathogens and herbivores to a warming experiment. Ecology 85(9): 2570-2581. doi: 10.1890/03-0182.

Roy-Léveillée, P., Burn, C.R., and McDonald, I.D. 2014. Vegetation-permafrost relations within the forest-tundra ecotone near Old Crow, Northern Yukon, Canada. Permafr. Periglac. Process. 25(2): 127-135. doi: 10.1002/ppp.1805.

Rumpf, S.B., Semenchuk, P.R., Dullinger, S., and Cooper, E.J. 2014. Idiosyncratic responses of high arctic plants to changing snow regimes. PLoS ONE, 9(2): e86281. doi: 10.1371/journal.pone.0086281.

Saccone, P., Morin, S., Baptist, F., Bonneville, J.M., Colace, M.P., Domine, F., et al. 2013. The effects of snowpack properties and plant strategies on litter decomposition during winter in subalpine meadows. Plant Soil 363(1-2): 215-229. doi: 10.1007/s11104-012-1307-3.

Sakai, A., and Larcher, W. 1987. Frost survival of plants. In Responses and adaptation to freezing stress. SpringerVerlag, Berlin/Heidelberg/New York. 321 p.

Sanders-DeMott, R., and Templer, P.H. 2017. What about winter? Integrating the missing season into climate change experiments in seasonally snow covered ecosystems. Methods Ecol. Evol.. 8(10): 1183-1191. doi: 10.1111/ 2041-210x.12780.

Schaefer, J.A., and Messier, F. 1995. Scale-dependent correlations of Arctic vegetation and snow cover. Arct. Alp. Res. 27(1): 38-43. doi: 10.2307/1552066.

Schimel, J.P., Bilbrough, C., and Welker, J.A. 2004. Increased snow depth affects microbial activity and nitrogen mineralization in two Arctic tundra communities. Soil Biol. Biochem. 36(2): 217-227. doi: 10.1016/ j.soilbio.2003.09.008.

Schimel, J.P., Fahnestock, J., Michaelson, G., Mikan, C., Ping, C.L., Romanovsky, V.E., and Welker, J. 2006. Coldseason production of $\mathrm{CO}_{2}$ in arctic soils: can laboratory and field estimates be reconciled through a simple modeling approach? Arct. Antarct. Alp. Res. 38(2): 249-256. doi: 10.1657/1523-0430(2006)38[249:CPOCIA]2.0.CO;2.

Schmidt, N.M., Mosbacher, J.B., Eitzinger, B., Vesterinen, E.J., and Roslin, T. 2018. High resistance towards herbivore-induced habitat change in a high Arctic arthropod community. Biol. Lett. 14(5). doi: 10.1098/rsbl.2018.0054.

Schollert, M., Kivimaenpaa, M., Michelsen, A., Blok, D., and Rinnan, R. 2017. Leaf anatomy, BVOC emission and $\mathrm{CO}_{2}$ exchange of arctic plants following snow addition and summer warming. Ann. Bot. 119(3): 433-445. doi: 10.1093/ aob/mcw237.

Schwieger, S., Kreyling, J., Milbau, A., and Blume-Werry, G. 2018. Autumnal warming does not change root phenology in two contrasting vegetation types of subarctic tundra. Plant Soil 424(1-2): 145-156. doi: 10.1007/s11104-0173343-5.

Sedlacek, J., Wheeler, J.A., Cortes, A.J., Bossdorf, O., Hoch, G., Lexer, C., et al. 2015. The response of the alpine dwarf shrub Salix herbacea to altered snowmelt timing: lessons from a multi-site transplant experiment. PloS ONE 10(4): e0122395. doi: 10.1371/journal.pone.0122395.

Semenchuk, P.R., Elberling, B., Amtorp, C., Winkler, J., Rumpf, S., Michelsen, A., and Cooper, E.J. 2015. Deeper snow alters soil nutrient availability and leaf nutrient status in high Arctic tundra. Biogeochemistry 124(1-3): 81-94. doi: $10.1007 / \mathrm{s} 10533-015-0082-7$.

Semenchuk, P.R., Elberling, B., and Cooper, E.J. 2013. Snow cover and extreme winter warming events control flower abundance of some, but not all species in high arctic Svalbard. Ecol. Evol. 3(8): 2586-2599. doi: 10.1002/ ece3.648.

Semenchuk, P.R., Christiansen, C.T., Grogan, P., Elberling, B., and Cooper, E.J. 2016a. Long-term experimentally deepened snow decreases growing-season respiration in a low- and high-arctic tundra ecosystem. J. Geophys. Res. Biogeosci. 121(5): 1236-1248. doi: 10.1002/2015JG003251.

Semenchuk, P.R., Gillespie, M.A.K., Rumpf, S.B., Baggesen, N., Elberling, B., and Cooper, E.J. 2016b. High Arctic plant phenology is determined by snowmelt patterns but duration of phenological periods is fixed: an example of periodicity. Environ. Res. Lett. 11(12): 125006. doi: 10.1088/1748-9326/11/12/125006.

Semenchuk, P.R., Krab, E.J., Hedenstrom, M., Phillips, C.A., Ancin-Murguzur, F.J., and Cooper, E.J. 2019. Soil organic carbon depletion and degradation in surface soil after long-term non-growing season warming in High Arctic Svalbard. Sci. Total Environ. 646: 158-167. doi: 10.1016/j.scitotenv.2018.07.150. PMID:30056226.

Seppälä, M. 1982. An experimental study of the formation of palsas. Proceedings of the 4th Canadian Permafrost Conference, Calgary, Alberta, 2-6 March 1981. pp. 36-42. Available from https://citeseerx.ist.psu.edu/viewdoc/ download?doi=10.1.1.583.1842\&rep=rep1\&type=pdf.

Siewert, M.B. 2018. High-resolution digital mapping of soil organic carbon in permafrost terrain using machine learning: a case study in a sub-Arctic peatland environment. Biogeosciences 15(6): 1663-1682. doi: 10.5194/bg-151663-2018.

Siewert, M.B., and Olofsson, J. 2020. Scale-dependency of Arctic ecosystem properties revealed by UAV. Environ. Res. Lett. 15(9): 094030. doi: 10.1088/1748-9326/aba20b.

Siren, A.P.K., Somos-Valenzuela, M., Callahan, C., Kilborn, J.R., Duclos, T., Tragert, C., and Morelli, T.L. 2018. Looking beyond wildlife: using remote cameras to evaluate accuracy of gridded snow data. Remote Sens. Ecol. Conserv. 4(4): 375-386. doi: 10.1002/rse2.85.

Slatyer, R.A., Umbers, K.D.L., and Arnold, P.A. 2021. Ecological responses to variation in seasonal snow cover. Conserv. Biol. 36(1): e13727. doi: 10.1111/cobi.13727.

Smith, J.D., Jackson, N., and Woolhouse, A.R. 1989. Fungal diseases of amenity turf grasses. 3rd ed. E. \& F.N. Spon, New York.

Smith, M.W., and Riseborough, D.W. 2002. Climate and the limits of permafrost: a zonal analysis. Permafr. Periglaci. Process. 13: 1-15. doi: 10.1002/ppp.410. 
Snider, C.S., Hsiang, T., Zhao, G.Y., and Griffith, M. 2000. Role of ice nucleation and antifreeze activities in pathogenesis and growth of snow molds. Phytopathology 90(4): 354-361. doi: 10.1094/PHYTO.2000.90.4.354.

Sokolov, A.I., Kharitonov, V.A., Pekkoev, A.N., and Krivenko, T.I. 2015. Preservation and growth of Pine cultivated by ball-rooted planting stock in Karelia. Lesnoy Zhurnal-For. J. (6): 46-56. doi: 10.17238/issn0536-1036.2015.6.46.

Spasojevic, M.J., Bowman, W.D., Humphries, H.C., Seastedt, T.R., and Suding, K.N. 2013. Changes in alpine vegetation over 21 years: Are patterns across a heterogeneous landscape consistent with predictions? Ecosphere 4(9): 1-18. doi: 10.1890/ES13-00133.1.

Speed, J.D.M., Woodin, S.J., Tømmervik, H., Tamstorf, M.P., and van der Wal, R. 2009. Predicting habitat utilization and extent of ecosystem disturbance by an increasing herbivore population. Ecosystems 12(3): 349-359. doi: 10.1007/s10021-009-9227-7.

Starr, G., and Oberbauer, S.F. 2003. Photosynthesis of arctic evergreens under snow: implications for tundra ecosystem carbon balance. Ecology 84(6): 1415-1420. doi: 10.1890/02-3154.

Starr, G., Oberbauer, S.F., and Ahlquist, L.E. 2008. The photosynthetic response of Alaskan tundra plants to increased season length and soil warming. Arct. Antarct. Alp. Res. 40(1): 181-191. doi: 10.1657/1523-0430(06015)[STARR]2.0.CO;2.

Starr, G., Oberbauer, S.F., and Pop, E.W. 2000. Effects of lengthened growing season and soil warming on the phenology and physiology of Polygonum bistorta. Global Change Biol. 6(3): 357-369. doi: 10.1046/j.13652486.2000.00316.x

Steltzer, H., Landry, C., Painter, T.H., Anderson, J., and Ayres, E. 2009. Biological consequences of earlier snowmelt from desert dust deposition in alpine landscapes. Proc. Natl. Acad. Sci. USA. 106(28): 11629-11634. doi: 10.1073/ pnas.0900758106.

Stemkovski, M., Pearse, W.D., Griffin, S.R., Pardee, G.L., Gibbs, J., Griswold, T., et al. 2020. Bee phenology is predicted by climatic variation and functional traits. Ecol. Lett. 23(11): 1589-1598. doi: 10.1111/ele.13583.

Sturm, M., Douglas, T., Racine, C., and Liston, G.E. 2005a. Changing snow and shrub conditions affect albedo with global implications. J. Geophys. Res. Biogeosci. 110(G1): G01004. doi:10.1029/2005JG000013.

Sturm, M., Holmgren, J., and Liston, G.E. 1995. A seasonal snow cover classification-system for local to global applications. J. Clim. 8(5): 1261-1283. doi: 10.1175/1520-0442(1995)008<1261:ASSCCS>2.0.CO;2.

Sturm, M., McFadden, J.P., Liston, G.E., Chapin, F.S., Racine, C.H., and Holmgren, J. 2001. Snow-shrub interactions in Arctic tundra: a hypothesis with climatic implications. J. Clim. 14(3): 336-344. doi: 10.1175/1520-0442(2001) 014<0336:SSIIAT>2.0.CO;2.

Sturm, M., Schimel, J., Michaelson, G., Welker, J.M., Oberbauer, S.F., Liston, G.E., et al. 2005b. Winter biological processes could help convert arctic tundra to shrubland. Bioscience 55(1): 17-26. doi: 10.1641/0006-3568(2005) 055[0017:WBPCHC]2.0.CO;2.

Sullivan, P.F., Stokes, M.C., McMillan, C.K., and Weintraub, M.N. 2020. Labile carbon limits late winter microbial activity near Arctic treeline. Nat. Commun. 11(1): 4024. doi:10.1038/s41467-020-17790-5.

Sullivan, P.F., Welker, J.M., Arens, S.J.T., and Sveinbjornsson, B. 2008. Continuous estimates of $\mathrm{CO}_{2}$ efflux from Arctic and boreal soils during the snow-covered season in Alaska. J. Geophys. Res. Biogeosci. 113(G4): G04009. doi: 10.1029/2008JG000715.

Suzuki, R.O. 2014. Combined effects of warming, snowmelt timing, and soil disturbance on vegetative development in a grassland community. Plant Ecol. 215(12): 1399-1408. doi: 10.1007/s11258-014-0396-x.

Tape, K.D., Lord, R., Marshall, H.P., and Ruess, R.W. 2010. Snow-mediated ptarmigan browsing and shrub expansion in Arctic Alaska. Ecoscience 17(2): 186-193. doi: 10.2980/17-2-3323.

Thompson, K.L., Zuckerberg, B., Porter, W.P., and Pauli, J.N. 2021. The decline of a hidden and expansive microhabitat: the subnivium. Front. Ecol. Environ. 19(5): 268-273. doi:10.1002/fee.2337.

Torp, M., Olofsson, J., Witzell, J., and Baxter, R. 2010a. Snow-induced changes in dwarf birch chemistry increase moth larval growth rate and level of herbivory. Polar Biol. 33(5): 693-702. doi: 10.1007/s00300-009-0744-9.

Torp, M., Witzell, J., Baxter, R., and Olofsson, J. 2010b. The effect of snow on plant chemistry and invertebrate herbivory: experimental manipulations along a natural snow gradient. Ecosystems 13(5): 741-751. doi: 10.1007/s10021010-9351-4.

Tranquillini, W. 1982. Frost-drought and its ecological significance. In Physiological plant ecology II. Encyclopedia of plant physiology (New Series). Vol. 12/B. Edited by O.L. Lange, Park S. Nobel, C. B. Osmond, H. Ziegler. Springer, Berlin, Heidelberg. pp. 379-400.

Treharne, R., Bjerke, J.W., Tømmervik, H., and Phoenix, G.K. 2020. Extreme event impacts on $\mathrm{CO}_{2}$ fluxes across a range of high latitude, shrub-dominated ecosystems. Environ. Res. Lett. 15(10): 104084. doi: 10.1088/1748-9326/ abb0b1.

Treharne, R., Bjerke, J.W., Tømmervik, H., Stendardi, L., and Phoenix, G.K. 2019. Arctic browning: impacts of extreme climatic events on heathland ecosystem $\mathrm{CO}_{2}$ fluxes. Global Change Biol. 25(2): 489-503. doi: 10.1111/ gcb.14500.

Trenberth, K.E. 2011. Changes in precipitation with climate change. Clim. Res. 47(1-2): 123-138. doi: 10.3354/ cr00953.

Tulp, I., and Schekkerman, H. 2008. Has prey availability for arctic birds advanced with climate change? Hindcasting the abundance of tundra arthropods using weather and seasonal variation. Arctic 61(1): 48-60.

Tutton, R.J., and Way, R.G. 2021. A low-cost method for monitoring snow characteristics at remote field sites. Cryosphere 15(1): 1-15. doi: 10.5194/tc-15-1-2021.

van Gestel, N., Crowther, T.W., Machmuller, M.B., Carey, J.C., Allison, S.D., Blair, J.M., et al. 2018. Predicting soil carbon loss with warming reply. Nature 554(7693): E7-E8. doi: 10.1038/nature25745. 
Vandvik, V., Skarpaas, O., Klanderud, K., Telford, R.J., Halbritter, A.H., and Goldberg, D.E. 2020. Biotic rescaling reveals importance of species interactions for variation in biodiversity responses to climate change. Proc. Natl. Acad. Sci. USA. 117(37): 22858-22865. doi: 10.1073/pnas.2003377117.

Venn, S., Pickering, C., and Green, K. 2014. Spatial and temporal functional changes in alpine summit vegetation are driven by increases in shrubs and graminoids. AoB Plants 6: plu008. doi: 10.1093/aobpla/plu008.

Venn, S.E., and Morgan, J.W. 2007. Phytomass and phenology of three alpine snowpatch species across a natural snowmelt gradient. Aust. J. Bot. 55(4): 450-456. doi: 10.1071/BT06003.

Venn, S.E., Morgan, J.W., and Lord, J.M. 2013. Foliar freezing resistance of Australian alpine plants over the growing season. Austral Ecol. 38(2): 152-161. doi: 10.1111/j.1442-9993.2012.02387.x.

Vikhamar-Schuler, D., Isaksen, K., Haugen, J.E., Tømmervik, H., Luks, B., Schuler, T.V., and Bjerke, J.W. 2016. Changes in winter warming events in the Nordic Arctic region. J. Clim. 29(17): 6223-6244. doi: 10.1175/JCLI-D-150763.1.

Vitasse, Y., Schneider, L., Rixen, C., Christen, D., and Rebetez, M. 2018. Increase in the risk of exposure of forest and fruit trees to spring frosts at higher elevations in Switzerland over the last four decades. Agric. Forest Meteorol. 248: 60-69. doi: 10.1016/j.agrformet.2017.09.005.

Wadgymar, S.M., Mactavish, R.M., and Anderson, J.T. 2019. Transgenerational and within-generation plasticity in response to climate change: insights from a manipulative field experiment across an elevational gradient (vol 192, 698, 2018). Am. Nat. 193(2): 318-319. doi: 10.1086/701856.

Walker, B., Wilcox, E.J., and Marsh, P. 2021. Accuracy assessment of late winter snow depth mapping for tundra environments using Structure-from-Motion photogrammetry. Arct. Sci. 7(3): 588-604. doi: 10.1139/as-2020-0006.

Walker, D.A., Epstein, H.E., Gould, W.A., Kelley, A.M., Kade, A.N., Knudson, J.A., et al. 2004. Frost-boil ecosystems: complex interactions between landforms, soils, vegetation and climate. Permafr. Periglac. Process. 15(2): 171-188. doi: 10.1002/ppp.487.

Walker, D.A., Halfpenny, J.C., Walker, M.D., and Wessman, C.A. 1993. Long-term studies of snow-vegetation interactions. Bioscience 43(5): 287-301. doi: 10.2307/1312061.

Walker, M.D., Walker, D.A., Welker, J.M., Arft, A.M., Bardsley, T., Brooks, P.D., et al. 1999. Long-term experimental manipulation of winter snow regime and summer temperature in arctic and alpine tundra. Hydrol. Process. 13(14-15): 2315-2330. doi: 10.1002/(SICI)1099-1085(199910)13:14/15<2315::AID-HYP888> 3.0.CO;2-A.

Walsh, N.E., McCabe, T.R., Welker, J.M., and Parsons, A.N. 1997. Experimental manipulations of snow-depth: effects on nutrient content of caribou forage. Global Change Biol. 3: 158-164. doi: 10.1111/j.1365-2486.1997.gcb142.x.

Wang, Z., Kim, Y., Seo, H., Um, M.J., and Mao, J.F. 2019. Permafrost response to vegetation greenness variation in the Arctic tundra through positive feedback in surface air temperature and snow cover. Environm. Res. Lett. 14(4): 044024. doi: 10.1088/1748-9326/ab0839.

Way, R.G., and Lapalme, C.M. 2021. Does tall vegetation warm or cool the ground surface? Constraining the ground thermal impacts of upright vegetation in northern environments. Environ. Res. Lett. 16(5): 054077. doi: 10.1088/ 1748-9326/abef31.

Way, R.G., and Lewkowicz, A.G. 2018. Environmental controls on ground temperature and permafrost in Labrador, northeast Canada. Permafr. Periglac. Process. 29(2): 73-85. doi:10.1002/ppp.1972.

Way, R.G., Lewkowicz, A.G., and Zhang, Y. 2018. Characteristics and fate of isolated permafrost patches in coastal Labrador, Canada. Cryosphere 12(8): 2667-2688. doi:10.5194/tc-12-2667-2018.

Weedon, J.T., Aerts, R., Kowalchuk, G.A., and van Bodegom, P.M. 2014. No effects of experimental warming but contrasting seasonal patterns for soil peptidase and glycosidase enzymes in a sub-arctic peat bog. Biogeochemistry 117(1): 55-66. doi: 10.1007/s10533-013-9870-0.

Weedon, J.T., Kowalchuk, G.A., Aerts, R., van Hal, J., van Logtestijn, R., Tas, N., et al. 2012. Summer warming accelerates sub-Arctic peatland nitrogen cycling without changing enzyme pools or microbial community structure. Global Change Biol. 18(1): 138-150. doi: 10.1111/j.1365-2486.2011.02548.x.

Welker, J.M., Molau, U., Parsons, A.N., Robinson, C.H., and Wookey, P.A. 1997. Responses of Dryas octopetala to ITEX environmental manipulations: a synthesis with circumpolar comparisons. Global Change Biol. 3: 61-73. doi: 10.1111/j.1365-2486.1997.gcb143.x.

Welker, J.M., Fahnestock, J.T., and Jones, M.H. 2000. Annual $\mathrm{CO}_{2}$ flux in dry and moist arctic tundra: field responses to increases in summer temperatures and winter snow depth. Clim. Change. 44(1-2): 139-150. doi: 10.1023/A: 1005555012742.

Welker, J.M., Fahnestock, J.T., Sullivan, P.F., and Chimner, R.A. 2005a. Leaf mineral nutrition of Arctic plants in response to warming and deeper snow in northern Alaska. Oikos 109(1): 167-177. doi: 10.1111/j.00301299.2005.13264.x.

Welker, J.M., Rayback, S., and Henry, G.H.R. 2005b. Arctic and North Atlantic oscillation phase changes are recorded in the isotopes $\left(\delta^{18} \mathrm{O}\right.$ and $\left.\delta^{13} \mathrm{C}\right)$ of Cassiope tetragona plants. Global Change Biol. 11(7): 997-1002. doi: 10.1111/j.1365-2486.2005.00961.x.

Westergaard-Nielsen, A., Balstrom, T., Treier, U.A., Normand, S., and Elberling, B. 2020. Estimating meltwater retention and associated nitrate redistribution during snowmelt in an Arctic tundra landscape. Environ. Res. Lett. 15(3): 034025. doi: 10.1088/1748-9326/ab57b1.

Westermann, S., Boike, J., Langer, M., Schuler, T.V., and Etzelmuller, B. 2011. Modeling the impact of wintertime rain events on the thermal regime of permafrost. Cryosphere 5(4): 945-959. doi: 10.5194/tc-5-945-2011.

Wheeler, J.A., Cortes, A.J., Sedlacek, J., Karrenberg, S., van Kleunen, M., Wipf, S., Hoch, G., Bossdorf, O., and Rixen, C. 2016. The snow and the willows: earlier spring snowmelt reduces performance in the low-lying alpine shrub Salix herbacea. J. Ecol. 104(4): 1041-1050. doi: 10.1111/1365-2745.12579. 
Wickham, H. 2016. ggplot2: elegant graphics for data analysis. Springer-Verlag, New York.

Wieder, W.R., Knowles, J.F., Blanken, P.D., Swenson, S.C., and Suding, K.N. 2017. Ecosystem function in complex mountain terrain: combining models and long-term observations to advance process-based understanding. J. Geophys. Res. Biogeosci. 122(4): 825-845. doi: 10.1002/2016JG003704.

Wilcox, E.J., Keim, D., de Jong, T., Walker, B., Sonnentag, O., Sniderhan, A.E., et al. 2019. Tundra shrub expansion may amplify permafrost thaw by advancing snowmelt timing. Arct. Sci. 5(4): 202-217. doi: 10.1139/as-2018-0028.

Williams, R.J., Wahren, C.H., Stott, K.A.J., Camac, J.S., White, M., Burns, E., et al. 2015. An International Union for the Conservation of Nature Red List ecosystems risk assessment for alpine snow patch herbfields, SouthEastern Australia. Austral Ecol. 40(4): 433-443. doi: 10.1111/aec.12266.

Winkler, D.E., Amagai, Y., Huxman, T.E., Kaneko, M., and Kudo, G. 2016. Seasonal dry-down rates and high stress tolerance promote bamboo invasion above and below treeline. Plant Ecol. 217(10): 1219-1234. doi: 10.1007/s11258016-0649-y.

Wipf, S. 2010. Phenology, growth, and fecundity of eight subarctic tundra species in response to snowmelt manipulations. Plant Ecol. 207(1): 53-66. doi: 10.1007/s11258-009-9653-9.

Wipf, S., and Rixen, C. 2010. Winter climate change in arctic and alpine ecosystems: a review of snow manipulation experiments. Polar Res. 29: 95-109. doi: 10.1111/j.1751-8369.2010.00153.x.

Wipf, S., Rixen, C., and Mulder, C.P.H. 2006. Advanced snowmelt causes shift towards positive neighbour interactions in a subarctic tundra community. Global Change Biol. 12(8): 1496-1506. doi: 10.1111/j.13652486.2006.01185.x.

Wipf, S., Stoeckli, V., and Bebi, P. 2009. Winter climate change in alpine tundra: plant responses to changes in snow depth and snowmelt timing. Clim. Change. 94: 105-121. doi: 10.1007/s10584-009-9546-x.

Wolkovich, E.M., Cook, B.I., Allen, J.M., Crimmins, T.M., Betancourt, J.L., Travers, S.E., et al. 2012. Warming experiments underpredict plant phenological responses to climate change. Nature 485(7399): 494-497. doi: 10.1038/ nature11014.

Xu, W.Y., Prieme, A., Cooper, E.J., Morsdorf, M.A., Semenchuk, P., Elberling, B., Grogan, P., and Ambus, P.L. 2021. Deepened snow enhances gross nitrogen cycling among Pan-Arctic tundra soils during both winter and summer. Soil Biol. Biochem. 160: 108356. doi: 10.1016/j.soilbio.2021.108356.

Yang, Y., Halbritter, A.H., Klanderud, K., Telford, R.J., Wang, G.X., and Vandvik, V. 2018. Transplants, Open Top Chambers (OTCs) and gradient studies ask different questions in climate change effects studies. Front. Plant Sci. 9: 1574. doi: 10.3389/fpls.2018.01574.

Yoshino, M.M. 1984. Thermal belt and cold air drainage on the mountain slope and cold air lake in the basin at quiet, clear night. GeoJournal 8(3): 235-250. doi: 10.1007/BF00446473.

Zeng, H.Q., and Jia, G.S. 2013. Impacts of snow cover on vegetation phenology in the arctic from satellite data. Adv. Atmos. Sci. 30(5): 1421-1432. doi:10.1007/s00376-012-2173-x.

Zhang, T.J. 2005. Influence of the seasonal snow cover on the ground thermal regime: an overview. Rev. Geophys. 43(4): RG4002. doi: 10.1029/2004RG000157.

Zhang, Y., Chen, W., and Riseborough, D.W. 2008. Modeling long-term dynamics of snow and their impacts on permafrost in Canada. Proceedings of the 9th International Conference on Permafrost. 28 June - 3 July 2008, Fairbanks, Alaska, United States of America. pp. 2055-2060.

Zhang, Y., Sherstiukov, A.B., Qian, B., Kokelj, S.V., and Lantz, T.C. 2018. Impacts of snow on soil temperature observed across the circumpolar north. Environ. Res. Lett. 13: 044012. doi: 10.1088/1748-9326/aab1e7. 